\title{
Synthesis, characterisation and ethylene polymerisation performance of silyl bridged peralkylated bis(indenyl) zirconocenes
}

Phakpoom Angpanitcharoen, Jessica V. Lamb, Zoë R. Turner, Jean-Charles Buffet and Dermot O'Hare*

Chemistry Research Laboratory, Department of Chemistry, University of Oxford, 12 Mansfield Road, OX1 3TA Oxford, UK. E-mail: dermot.ohare@ chem.ox.ac.uk

\begin{abstract}
Six new peralkylated bis(indenyl) zirconocene complexes have been synthesised and fully characterised; $\mathrm{rac}_{-}{ }^{\mathrm{Me}_{2}} \mathrm{SB}\left({ }^{3-\mathrm{Et}} \mathrm{I}^{*}\right) \mathrm{ZrX}_{2}$ and meso- $^{{ }^{\mathrm{Me}}}{ }_{2} \mathrm{SB}\left({ }^{3-\mathrm{Et}} \mathrm{I}^{*}\right) \mathrm{ZrX} 2\left(\mathrm{X}=\mathrm{Cl}, \mathrm{Br}\right.$ and $\left.\mathrm{CH}_{2} \mathrm{Ph}\right)$.

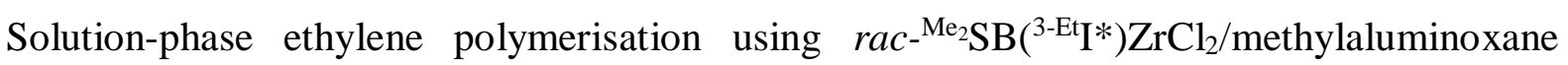
(MAO) and slurry-phase ethylene polymerisation using $\left.\mathrm{rac}^{-{ }^{\mathrm{Me}}{ }_{2} \mathrm{SB}}{ }^{3-\mathrm{Et}} \mathrm{I}^{*}\right) \mathrm{ZrCl}_{2}$ immobilised on solid polymethylaluminoxane (sMAO), MAO modified layered double hydroxide (LDHMAO) and MAO modified silica (SSMAO) were studied. Polymerisation conditions were optimised for sMAO- $r a c-{ }^{\mathrm{Me}_{2}} \mathrm{SB}\left({ }^{3-\mathrm{Et}} \mathrm{I}^{*}\right) \mathrm{ZrCl}_{2}$ and applied to the other catalysts. A 75:25 mixture of racand $m e s o-{ }^{\mathrm{Me}_{2}} \mathrm{SB}\left({ }^{3-\mathrm{Et}} \mathrm{I}^{*}\right) \mathrm{Zr}\left(\mathrm{CH}_{2} \mathrm{Ph}\right)_{2}$ supported on sMAO showed the highest polymerisation activities (4832 $\mathrm{kg}_{\mathrm{PE}} \mathrm{mol}_{\mathrm{Zr}}^{-1} \mathrm{~h}^{-1} \mathrm{bar}^{-1}$ at $60{ }^{\circ} \mathrm{C}$ ), producing high density polyethylenes (HDPE) with modest molecular weight $\left(M_{\mathrm{w}}\right.$ of $336 \mathrm{~kg} \mathrm{~mol}^{-1}$ at $\left.60{ }^{\circ} \mathrm{C}\right)$ and molecular weight distributions $\left(M_{\mathrm{w}} / M_{\mathrm{n}}\right)$ less than 3.2. $\mathrm{sMAO}-\mathrm{rac}^{-}{ }^{\mathrm{Me}_{2}} \mathrm{SB}\left({ }^{3-\mathrm{Et}} \mathrm{I}^{*}\right) \mathrm{ZrCl}_{2}$ was found to be responsive to $\mathrm{H}_{2}$ in a high-throughput screening system, producing polyethylenes with low molecular weights $\left(M_{\mathrm{w}}\right.$ of $41 \mathrm{~kg} \mathrm{~mol}^{-1}$ with $\left.1.6 \% \mathrm{H}_{2}\right)$. In the same high-throughput system, slurry-phase ethylene polymerisation in the presence of 1-hexene comonomer was shown to increase the polymerisation activity of sMAO- $\left.r a c-{ }^{\mathrm{Me}_{2}} \mathrm{SB}\left({ }^{3-\mathrm{Et}_{\mathrm{I}}} *\right) \mathrm{ZrCl}_{2}\right)$ compared to polymerisation in the same system without 1-hexene.
\end{abstract}

\section{Keywords}

Zirconocenes, polymerisation, ethylene, solid polymethylaluminoxane, peralkylated bis(indenyl)

\section{Introduction}

Group 4 metallocenes are generally defined as $\mathrm{d}^{0}$, pseudo-tetrahedral organometallic compounds in which the transition metal atom bears two $\eta^{5}$-cyclopentadienyl-based ligands 
and two $\sigma$-ligands. Upon activation by co-catalysts (such as methylaluminoxane; MAO), the resulting electrophilic alkyl metallocene cations, stabilised by weakly coordinating anions, are highly active for $\alpha$-olefin polymerisation.[1-5] Ansa-bridges can impart significant control over the activity and structure of metallocene catalysts, such as introducing additional stereochemistry, which is exemplified in the rac-and meso-isomers of bridged indenyl complexes.[6] Group 4 ansa-bridged indenyl and permethylindenyl complexes, such as rac-dichloro(dimethylsilylenebis(1-indenyl))zirconium(IV) $\quad\left(\mathrm{rac}_{-}{ }^{\mathrm{Me}_{2}} \mathrm{SBIZrCl}_{2}\right) \quad$ and rac-dichloro(dimethylsilylenebis(hexamethyl-1-indenyl))zirconium(IV) $\left(\mathrm{rac}^{\mathrm{Me}_{2}} \mathrm{SBI}^{*} \mathrm{ZrCl}_{2}\right)$, have been shown to be very active for ethylene polymerisation. [7-10] Permethylation of the indenyl ring can lead to enhanced complex stability compared to the unsubstituted analogues, attributed to increased inductive donation and steric bulk around the metal centre.[11] It is proposed that this can lead to additional stabilisation of the cationic polymerisation intermediates and can therefore increase polymerisation activity. Furthermore, it has been shown that introducing alkyl groups at the 3-positions of unsubstituted indenyl ligands leads to increases in the stability and ethylene polymerisation activities of the corresponding complexes.[12-14]

These 'single-site' metallocene catalysts enable the production of polyolefins with tuneable molecular structures, stereochemistries and molecular weight distributions (MWD). Yet, they are rarely used for industrial polymer production due to their incompatibility with the existing slurry-phase or gas-phase olefin polymerisation infrastructure.[15] By immobilising metallocenes onto support materials this problem may be overcome, and the advantages of metallocene catalysts (including narrow MWD, high activity and precise control over polymer microstructure) are preserved.[16]

Silica $\left(\mathrm{SiO}_{2}\right)$ is the most common inorganic support for metallocene complexes.[15, 17] Impregnation of MAO, forming MAO modified silica (SSMAO), is required in order to activate the support.[10, 15, 18-21] Recently, aqueous miscible organic layered double hydroxides (AMO-LDHs), a class of anionic clays consisting of positively charged Brucite-like layers with weakly bound anions intercalated between them, activated with MAO (LDHMAO), have been reported as catalyst supports for olefin polymerisation.[10, 22, 23] AMO-LDH supports are simple to synthesise on a large scale, more cost-effective than silica and show no evidence of reactor fouling or catalyst leaching, making them viable options for industrial processes.[24] Solid polymethylaluminoxane (sMAO), an insoluble, oligomeric product of the incomplete hydrolysis of trimethylaluminium (TMA), has also recently been explored as a 
support for metallocene complexes.[21, 25-27] sMAO can act a bifunctional activator and support without further modification, $[28,29]$ and has been found to be a very efficient support for metallocene catalysts.[27, 28, 30, 31]

Herein, we report the synthesis and characterisation of a new family of peralkylated bis(indenyl) group 4 metallocenes. Looking to improve the ethylene polymerisation activity of ${ }^{\mathrm{Me}_{2}} \mathrm{SBI}^{*} \mathrm{ZrX}{ }_{2}$-type complexes, we have introduced ethyl groups at the 3-position of the permethylindenyl rings, forming complexes of the type ${ }^{\mathrm{Me}_{2}} \mathrm{SB}\left({ }^{3-\mathrm{Et}^{*}}\right) \mathrm{ZrX}_{2}$. The homogeneous ethylene polymerisation activities, and heterogeneous ethylene polymerisation activities of the complexes when immobilised on inorganic solid supports (SSMAO, LDHMAO and SMAO) are discussed. One catalyst is also evaluated for its potential industrial applications, including the synthesis of low molecular weight polyethylenes using dihydrogen $\left(\mathrm{H}_{2}\right)$ as a chain transfer agent, and linear low-density polyethylene (LLDPE) using 1-hexene as a comonomer.

\section{Results and Discussion}

\subsection{Synthesis of ${ }^{\mathrm{Me}_{2}} \mathrm{SB}\left({ }^{3-\mathrm{Et}} \mathrm{I}^{*}\right) \mathrm{H}_{2}$}

3-ethyl-2,4,5,6,7-pentamethylindenyl lithium ( ${ }^{3-E t} \mathrm{Ind}^{\#} \mathrm{Li}$ ) was synthesised according to a previously reported procedure.[20] One equivalent $\mathrm{Me}_{2} \mathrm{SiCl}_{2}$ was added to two equivalents ${ }^{3-E t} \mathrm{Ind}^{\#} \mathrm{Li}$ at $0{ }^{\circ} \mathrm{C}$ and stirred at room temperature for 16 hours (Scheme 1). Following work-up, ${ }^{\mathrm{Me}_{2}} \mathrm{SB}\left({ }^{3-\mathrm{Et}}{ }^{*}\right) \mathrm{H}_{2}$ was isolated as an off-white solid in 53\% yield as a 50:50 mixture of $\mathrm{rac}$ - and meso- ${ }^{\mathrm{Me}_{2}} \mathrm{SB}\left({ }^{3-\mathrm{Et}} \mathrm{I}^{*}\right) \mathrm{H}_{2}$. The ${ }^{1} \mathrm{H} \mathrm{NMR}$ spectrum shows that the two indenyl rings are magnetically equivalent for both isomers (Figure S1). For $\mathrm{rac}_{-}{ }^{\mathrm{Me}_{2}} \mathrm{SB}\left({ }^{3-\mathrm{Et}} \mathrm{I}^{*}\right) \mathrm{H}_{2}$, the two methyl groups on the silyl bridge appear as a singlet, indicating that they are enantiotopic and the isomer is racemic. However, for meso- ${ }^{\mathrm{Me}_{2}} \mathrm{SB}\left({ }^{3-\mathrm{Et}} \mathrm{I}^{*}\right) \mathrm{H}_{2}$, the methyl groups on the silyl bridge appear as two singlets and are therefore diastereotopic.

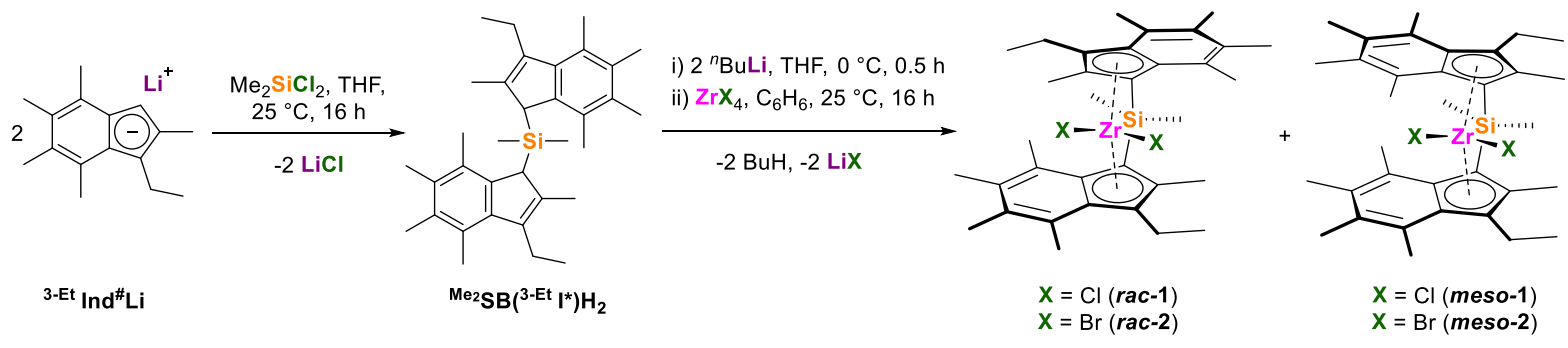

Scheme 1. Synthesis of rac- and meso- ${ }^{\mathrm{Me}_{2}} \mathrm{SB}^{\left.3-\mathrm{Et}^{*}\right)} \mathrm{ZrCl}_{2}$ (1) and rac- and meso $-{ }^{\mathrm{Me}_{2}} \mathrm{SB}\left({ }^{3-\mathrm{Et}} \mathrm{I}^{*}\right) \mathrm{ZrBr}_{2}(2)$ via ${ }^{\mathrm{Me}_{2}} \mathrm{SB}\left({ }^{3-\mathrm{Et}} \mathrm{I}^{*}\right) \mathrm{H}_{2}$. 
Colourless crystals of $\mathrm{rac}^{-{ }^{\mathrm{Me}} 2} \mathrm{SB}\left({ }^{3-\mathrm{E}} \mathrm{I} *\right) \mathrm{H}_{2}$ suitable for a single crystal X-ray diffraction study were grown from $\mathrm{Et}_{2} \mathrm{O}$ at $-30{ }^{\circ} \mathrm{C}$ (Figure 1). The Flack parameter of 0.38(16) (near 0.5) indicates that the crystals are likely racemic. The crystal structure also confirms the position of the $\mathrm{C}(2)=\mathrm{C}(3)$ and $\mathrm{C}(17)=\mathrm{C}(18)$ double bonds with an average bond length of 1.351(6) $\AA$ (bond lengths of 1.54 and $1.34 \AA$ are expected for $\mathrm{C}-\mathrm{C}$ single bonds and $\mathrm{C}=\mathrm{C}$ double bonds, respectively). The structure displays a similar average $\mathrm{Si}-\mathrm{C}_{\text {Ind }}$ bond length to $\mathrm{rac}^{-{ }^{\mathrm{Me}}} \mathrm{SBI}^{*} \mathrm{H}_{2}$ (1.934(4) and 1.939(6) Å respectively).[10]

(a)

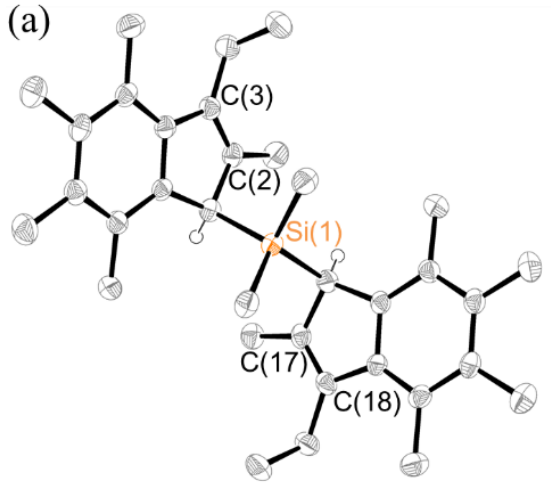

(d)

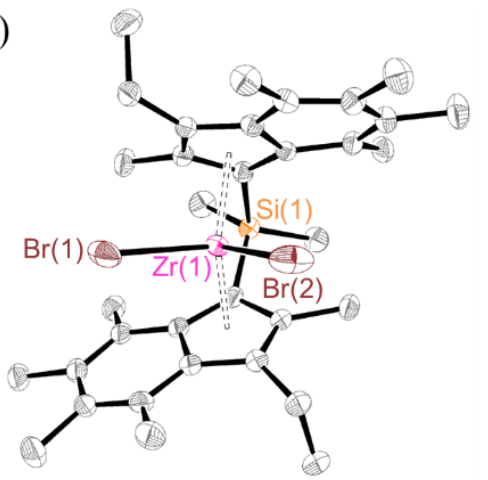

(b)

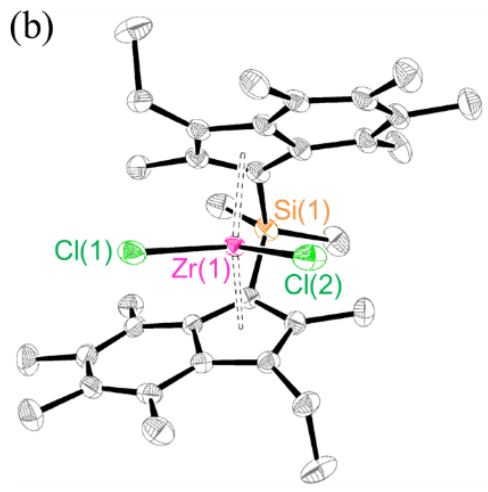

(e)

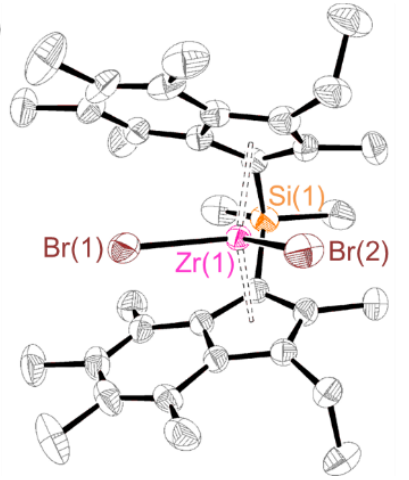

(c)
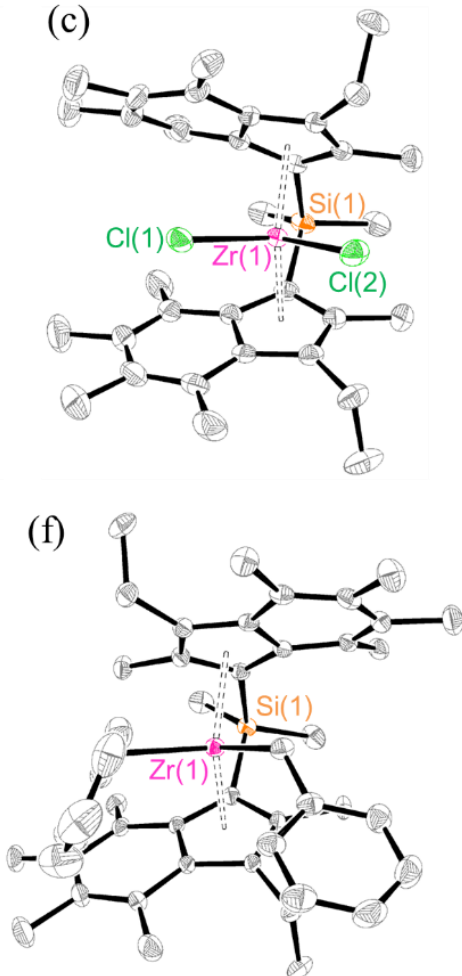

Figure 1. Molecular structures of (a) $r a c-{ }^{\mathrm{Me}_{2}} \mathrm{SB}\left({ }^{3-\mathrm{Et}} \mathrm{I}^{*}\right) \mathrm{H}_{2}$, (b) $r a c-{ }^{\mathrm{Me}_{2}} \mathrm{SB}\left({ }^{3-\mathrm{Et}} \mathrm{I}^{*}\right) \mathrm{ZrCl}_{2}$ (rac-1),

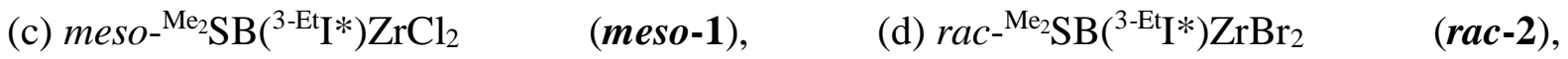
(e) meso- $^{-{ }_{2}}{ }_{2} \mathrm{SB}\left({ }^{3-\mathrm{Et}} \mathrm{I}^{*}\right) \mathrm{ZrBr}_{2}$ (meso-2) and (f) $\mathrm{rac}_{-}{ }^{\mathrm{Me}_{2}} \mathrm{SB}\left({ }^{3-\mathrm{Et}} \mathrm{I}^{*}\right) \mathrm{Zr}\left(\mathrm{CH}_{2} \mathrm{Ph}\right)_{2}$ (rac-3). Hydrogen atoms omitted for clarity (except for stereocentres), ellipsoids drawn at 50\% probability.

Table 4.1. Selected bond lengths $(\AA)$ and angles $\left({ }^{\circ}\right)$ for $\left.r a c-{ }^{\mathrm{Me}_{2}} \mathrm{SB}^{3-\mathrm{Et}} \mathrm{I}^{*}\right) \mathrm{ZrCl}_{2}$ (rac-1),

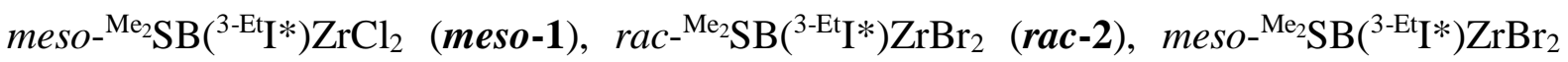
(meso-2) and $\mathrm{rac}_{-}{ }^{\mathrm{Me}_{2}} \mathrm{SB}\left({ }^{3-\mathrm{Et}} \mathrm{I}^{*}\right) \mathrm{Zr}\left(\mathrm{CH}_{2} \mathrm{Ph}\right)_{2}$ (rac-3).

\begin{tabular}{|c|c|c|c|c|c|c|}
\hline & Complex & Zr-X & $\mathbf{Z r}-C_{\text {cent }}$ & $\alpha$ & $\delta$ & $\boldsymbol{T A}$ \\
\hline$r a c-1$ & $r a c-{ }^{\mathrm{Me}_{2}} \mathrm{SB}\left({ }^{3-\mathrm{Et}} \mathrm{I}^{*}\right) \mathrm{ZrCl}_{2}$ & $\begin{array}{l}2.4186(7) \\
2.4295(7)\end{array}$ & $\begin{array}{l}2.2361(11) \\
2.2374(11)\end{array}$ & $58.21(13)$ & $129.54(4)$ & 144.92 \\
\hline
\end{tabular}




\begin{tabular}{|c|c|c|c|c|c|c|}
\hline meso-1 & meso- ${ }^{\mathrm{Me}_{2}} \mathrm{SB}\left({ }^{3-\mathrm{Et}} \mathrm{I} *\right) \mathrm{ZrCl}_{2}$ & $\begin{array}{l}2.4136(6) \\
2.4357(7)\end{array}$ & $\begin{array}{l}2.2513(11) \\
2.2410(11)\end{array}$ & $57.13(14)$ & $130.53(4)$ & 5.60 \\
\hline$r a c-2$ & $r a c-{ }^{\mathrm{Me}_{2}} \mathrm{SB}\left({ }^{3-\mathrm{Et}} \mathrm{I} *\right) \mathrm{ZrBr}_{2}$ & $\begin{array}{l}2.5861(5) \\
2.5656(5)\end{array}$ & $\begin{array}{l}2.2511(14) \\
2.2435(14)\end{array}$ & $59.65(18)$ & $129.14(5)$ & 144.99 \\
\hline meso-2 & meso- ${ }^{\mathrm{Me}_{2}} \mathrm{SB}\left({ }^{3-\mathrm{Et}} \mathrm{I}^{*}\right) \mathrm{ZrBr}_{2}$ & $\begin{array}{l}2.5635(8) \\
2.5945(9)\end{array}$ & $\begin{array}{c}2.244(2), \\
2.2389(19)\end{array}$ & $57.9(3)$ & $130.09(8)$ & 2.89 \\
\hline$r a c-3$ & $r a c-{ }^{\mathrm{Me}_{2}} \mathrm{SB}\left({ }^{3-\mathrm{Et}} \mathrm{I}^{*}\right) \mathrm{Zr}\left(\mathrm{CH}_{2} \mathrm{Ph}\right)_{2}$ & $\begin{array}{l}2.273(4) \\
2.334(4)\end{array}$ & $\begin{array}{l}2.2923(18) \\
2.3146(18)\end{array}$ & $63.2(2)$ & $128.84(7)$ & 146.78 \\
\hline
\end{tabular}

\subsection{Synthesis of ${ }^{\mathrm{Me}_{2}} \mathrm{SB}\left({ }^{3-\mathrm{Et}} \mathrm{I} *\right) \mathrm{ZrX}_{2}(\mathrm{X}=\mathrm{Cl}$ and $\mathrm{Br})$}

One equivalent ${ }^{\mathrm{Me}_{2}} \mathrm{SB}\left({ }^{3-\mathrm{Et}} \mathrm{I} *\right) \mathrm{H}_{2}$ was deprotonated with two equivalents ${ }^{n} \mathrm{BuLi}$ to yield $\left.{ }^{\mathrm{Me}_{2}} \mathrm{SB}^{3-\mathrm{Et}} \mathrm{I}^{*}\right) \mathrm{Li}_{2}$ as a yellow solid, which was then reacted with one equivalent $\mathrm{ZrX} 4(\mathrm{X}=\mathrm{Cl}$ and $\mathrm{Br}$ ). Following work up, ${ }^{\mathrm{Me}}{ }_{2} \mathrm{SB}\left({ }^{3-\mathrm{Et}} \mathrm{I}^{*}\right) \mathrm{ZrCl}_{2}$ (1) was isolated as an orange solid in $24 \%$ yield as a 50:50 mixture of rac- and meso- ${ }^{\mathrm{Me}_{2}} \mathrm{SB}\left({ }^{3-\mathrm{Et}^{*}}\right) \mathrm{ZrCl}_{2}$ (rac-1 and meso-1). Recrystallisation of the isomeric mixture in $\mathrm{Et}_{2} \mathrm{O}$ at $-30{ }^{\circ} \mathrm{C}$ yielded pure rac-1 as orange crystals. Following work up, $\left.{ }^{{ }^{\mathrm{e}} 2} \mathrm{SB}^{3-\mathrm{Et}}{ }^{*}\right) \mathrm{ZrBr}_{2}$ (2) was isolated as a red solid comprising of a 50:50 mixture of rac- and meso $\left.^{-{ }^{-{ }_{2}}{ }_{2}} \mathrm{SB}^{3-\mathrm{Et}}{ }^{*}\right) \mathrm{ZrBr}_{2}$ (rac-2 and meso-2) and impurities. Recrystallisation of the isomeric mixture in $\mathrm{Et}_{2} \mathrm{O}$ at $-30{ }^{\circ} \mathrm{C}$ yielded $\boldsymbol{r a c}-\mathbf{2}$ as orange crystals in $1 \%$ yield.

The ${ }^{1} \mathrm{H}$ NMR spectrum of $r a c-1$ shows that the indenyl rings and silyl methyl groups are magnetically equivalent; five singlets at $1.90-2.60 \mathrm{ppm}$ correspond to the methyl groups on the indenyl rings and a singlet at 1.14 ppm corresponds to the methyl groups on the silyl bridge (Figure S3). The diastereotopic methylene protons of the ethyl groups are observed as two doublet of quartets resonances at 2.71 and $3.30 \mathrm{ppm}$, while a triplet at $0.86 \mathrm{ppm}$ corresponds to the methyl protons of the ethyl groups. The ${ }^{1} \mathrm{H}$ NMR spectrum of $\mathbf{r a c}-\mathbf{2}$ shows an identical pattern to rac-1 (Figure S7). By subtracting the resonances corresponding to $r a c-1$ from the ${ }^{1} \mathrm{H}$ NMR spectrum of the 50:50 isomeric mixture of rac-1 and meso-1, the resonances corresponding to meso-1 can be assigned (Figure S5). 
Orange crystals of $\boldsymbol{r a c} \mathbf{- 1}$ and $\mathbf{m e s o - 1}$ suitable for single crystal X-ray diffraction studies were grown from the slow cooling of a hot pentane solution of the isomeric mixture and co-crystallised in the triclinic space group $P \overline{1}$. Orange crystals of rac-2 and meso-2 suitable for single crystal X-ray diffraction studies were grown by the slow evaporation of a $\mathrm{Et}_{2} \mathrm{O}$ solution of $r a c-2$ or a chloroform- $d_{1}$ solution of 50:50 rac-2 and meso-2, respectively. Both isomers crystallised in the monoclinic space group $P 2_{1} / c$ (as a racemic mixture for rac-2). Molecular structures are depicted in Figure 1, with selected bond lengths and angles presented in Table 1.

The average $\mathrm{Zr}-\mathrm{X}$ bond lengths of the rac- and meso-isomers are very similar; average $\mathrm{Zr}-\mathrm{Cl}$ of 2.424 and $2.425 \AA$ for rac-1 and meso-1 respectively and average $\mathrm{Zr}$ - $\mathrm{Br}$ of 2.576 and $2.579 \AA$ for $r a c-2$ and $\boldsymbol{m e s o - 2}$ respectively. The $\mathrm{Zr}-\mathrm{Br}$ bond lengths are longer than $\mathrm{Zr}-\mathrm{Cl}$ due to the increase in size of $\mathrm{Br}$ compared to $\mathrm{Cl}$. The $\mathrm{Zr}-\mathrm{Cl}$ bond lengths of $\mathbf{r a c}-\mathbf{1}$ are very similar to those of the permethylated analogue; average $\mathrm{Zr}-\mathrm{Cl}$ of 2.424 and $2.423 \AA$ for rac-1 and rac ${ }^{\mathrm{Me}_{2}} \mathrm{SBI}^{*} \mathrm{ZrCl}_{2}$, respectively.[10] The average $\mathrm{Zr}-\mathrm{Cp}_{\text {cent }}$ distances for the rac- and meso-isomers of 1 (2.237 and $2.246 \AA$, respectively) and 2 (2.247 and $2.241 \AA$, respectively) are very similar and show good agreement with reported values for similar structures.[10, 30, 32-34]

The ring tilt angle $(\alpha)$ for $r a c-1$ is in close agreement with $r a c-{ }^{\mathrm{Me}_{2}} \mathrm{SBI}^{*} \mathrm{ZrCl}_{2}$ (58.21 and 58.49 respectively), implying that the introduction of ethyl groups at the 3-position has no effect on ring tilt.[10] The torsion angles (the dihedral angle between the $\left[\mathrm{C}(2), \mathrm{C} \mathrm{p}_{\text {cent }}, \mathrm{Cp}_{\text {cent }}\right]$ and $\left[\mathrm{C}(2)^{\prime}\right.$, $\mathrm{Cp}_{\text {cent, }} \mathrm{Cp}_{\text {cent }}^{\prime}$ planes; TA) for rac $\mathbf{- 1}$ and rac -2 are very similar to rac $-{ }^{\mathrm{Me}_{2}} \mathrm{SBI}^{*} \mathrm{ZrCl}_{2}$ and rac-(SBI) $\mathrm{ZrCl}_{2}\left(144.92,144.99,145.15\right.$ and $145.20^{\circ}$ respectively)[9, 10] due to the geometric restriction of the silyl bridge. In comparison, when no restriction is present, the unbridged analogue $\mathrm{rac}$-(Ind $\left.{ }^{\#}\right)_{2} \mathrm{ZrCl}_{2}$ adopts near perfect 'anti' conformation with a TA value of $175.82^{\circ}$ in order to minimise steric interactions.[35] The same structural restriction can also be observed for $\boldsymbol{m e s o - 1}$ and $\boldsymbol{m e s o - 2}$ where TAs close to $0^{\circ}$ are observed (5.60 and $2.89^{\circ}$, respectively), while TA of $37.16^{\circ}$ is reported for unbridged meso- $\left(\mathrm{Ind}^{\#}\right)_{2} \mathrm{ZrCl}_{2}$.[35]

\subsection{Synthesis of ${ }^{\mathrm{Me}_{2}} \mathrm{SB}\left({ }^{3-\mathrm{Et}} \mathrm{I} *\right) \mathrm{Zr}\left(\mathrm{CH}_{2} \mathrm{Ph}\right)_{2}$}

One equivalent of a 50:50 mixture of rac- and meso- ${ }^{\mathrm{Me}_{2}} \mathrm{SB}\left({ }^{3-\mathrm{Et}} \mathrm{I}^{*}\right) \mathrm{ZrCl}_{2}$ (1) was reacted with two equivalents of $\mathrm{KCH}_{2} \mathrm{Ph}$ (Equation 1). Following work up, ${ }^{\mathrm{Me}_{2}} \mathrm{SB}\left({ }^{3-\mathrm{Et}} \mathrm{I}^{*}\right) \mathrm{Zr}\left(\mathrm{CH}_{2} \mathrm{Ph}\right)_{2}(3)$ was isolated as a 75:25 mixture of rac- and meso- ${ }^{\mathrm{Me}_{2}} \mathrm{SB}\left({ }^{3-\mathrm{E} t} \mathrm{I}^{*}\right) \mathrm{Zr}\left(\mathrm{CH}_{2} \mathrm{Ph}\right)_{2}($ rac -3 and $\boldsymbol{\text { meso-3}})$ as an orange-yellow solid in $83 \%$ yield. The change in the isomeric ratio from the parent complex suggests differences in solubility of the two isomers. 


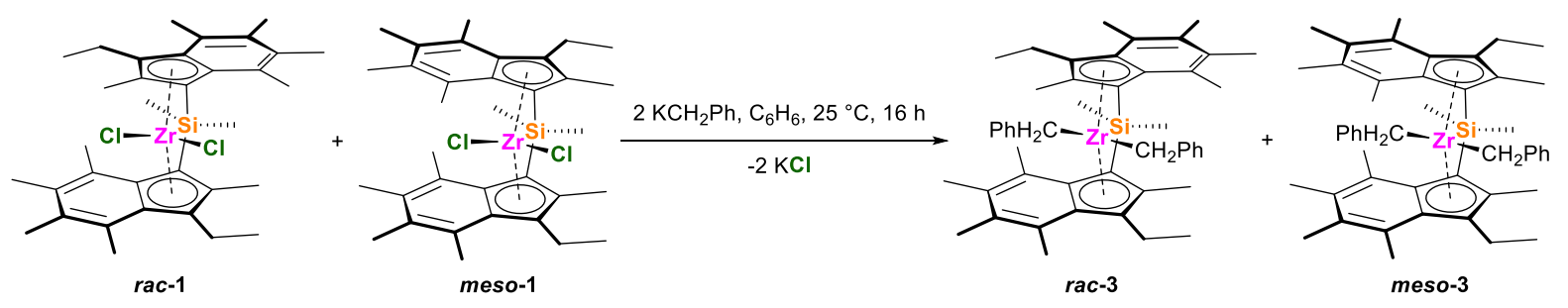

Equation 1. Synthesis of $\mathrm{rac}^{-{ }^{\mathrm{Me}}}{ }_{2} \mathrm{SB}\left({ }^{3-\mathrm{Et}} \mathrm{I}^{*}\right) \mathrm{Zr}\left(\mathrm{CH}_{2} \mathrm{Ph}\right)_{2}(\mathbf{3})$.

The two sets of resonances in the ${ }^{1} \mathrm{H}$ NMR spectrum of 75:25 rac-and $\boldsymbol{\text { meso-3 }}$ can be distinguished by the difference in integration and 2D NMR spectroscopy correlations (Figure S9). For both isomers, the two indenyl rings are magnetically equivalent. However, the $C_{2}$-symmetry of $\mathbf{r a c} \mathbf{- 3}$ results in magnetically equivalent benzyl and silyl methyl groups, while the $C_{\mathrm{s}}$-symmetry of $\mathbf{m e s o - 3}$ results in two magnetically inequivalent benzyl groups.

Orange crystals of $\mathbf{r a c} \mathbf{- 3}$ suitable for a single crystal X-ray diffraction study were grown from a pentane solution of the isomeric mixture at room temperature (Figure 1 and Table 1). The isomer crystallised in the triclinic space group $P \overline{1}$ as a racemic mixture. Comparison of rac-3 with the parent complex rac-1 highlights structure distortions caused by the bulky benzyl ligands; the $\alpha$ and TA values of $\boldsymbol{r a c - 3}$ (63.2 and $146.78^{\circ}$, respectively) are larger than for $\boldsymbol{r a c} \mathbf{- 1}$ (58.21 and $144.92^{\circ}$, respectively). The increased steric bulk of benzyl compared to chloride also causes increases in the $\mathrm{Zr}-\mathrm{C} \mathrm{p}_{\text {cent }}$ distances of rac $\mathbf{- 3}$ compared to rac-1 (average $\mathrm{Zr}-\mathrm{C} \mathrm{p}_{\text {cent }}$ of 2.303 and $2.237 \AA$ respectively); a trend also observed for ${ }^{\mathrm{Me}_{2}} \mathrm{SB}\left(\mathrm{Cp}, \mathrm{I}^{*}\right) \mathrm{ZrX}_{2}$ and meso-EBI* $\mathrm{ZrX}_{2}\left(\mathrm{X}=\mathrm{Cl}\right.$ and $\left.\mathrm{CH}_{2} \mathrm{Ph}\right) \cdot[25,30]$

\section{Ethylene polymerisation}

\subsection{Solution phase ethylene polymerisation}

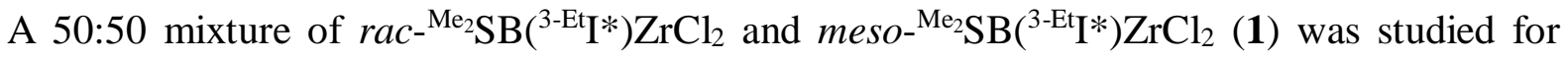
homogeneous ethylene polymerisation in $150 \mathrm{~mL}$ ampoules with $0.5 \mathrm{mg} \mathbf{1}$, methylaluminoxane (MAO) activator with an initial aluminium to zirconium ratio $\left(\left[\mathrm{Al} l_{\mathrm{MAO}}\right]_{0} /[\mathrm{Zr}]_{0}\right)$ of $500,50 \mathrm{~mL}$ hexane and 2 bar ethylene at $50-90{ }^{\circ} \mathrm{C}$. Polymerisations were run until stirring ceased (approximately 2 minutes).

1 shows decreasing polymerisation activities with increasing temperatures, likely due to the lack of thermal stability of metallocene complexes (Figure S15 and Table S2).[36] 1 is significantly more active than the unbridged analogue $\mathrm{rac}-\left({ }^{3-\mathrm{Et}} \mathrm{Ind}^{\#}\right)_{2} \mathrm{ZrCl}_{2}$ under the same polymerisation conditions (activities of 12423 and $1421 \mathrm{~kg}_{\mathrm{PE}}$ molzr$^{-1} \mathrm{~h}^{-1} \mathrm{bar}^{-1}$ respectively at 
$\left.60{ }^{\circ} \mathrm{C}\right)[20]$ due to the ansa-bridge opening up the metal centre and increasing the 'bite angle' of the metallocene complex.[37] 1 also displays higher polymerisation activities than the

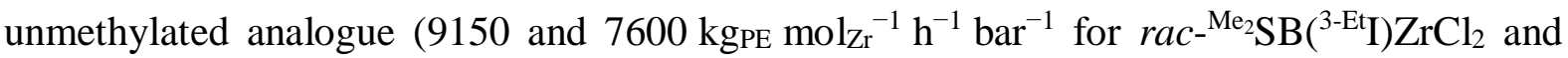
meso- ${ }^{\mathrm{Me}_{2}} \mathrm{SB}\left({ }^{3-\mathrm{Et}}\right) \mathrm{ZrCl}_{2}$, respectively, at $70{ }^{\circ} \mathrm{C}$ with $\left[\mathrm{Al}_{\mathrm{MAO}}\right]_{0} /[\mathrm{Zr}]_{0}$ of 1000 and 2 bar ethylene)[38] due to the increased inductive donation of ${ }^{3-E t}{ }^{*}$ compared to ${ }^{3-E t}$ I leading to increased stability. However, 1 shows lower polymerisation activities than the permethylated analogue ${ }^{\mathrm{Me}_{2}} \mathrm{SBI}^{*} \mathrm{ZrCl}_{2}$ (activity of $22622 \mathrm{~kg}_{\mathrm{PE}} \mathrm{molzr}^{-1} \mathrm{~h}^{-1} \mathrm{bar}^{-1}$ at $60{ }^{\circ} \mathrm{C}$ under similar polymerisation conditions with $\left[\mathrm{Al}_{\mathrm{MAO}}\right]_{0} /[\mathrm{Zr}]_{0}$ of 2000)[10] and related

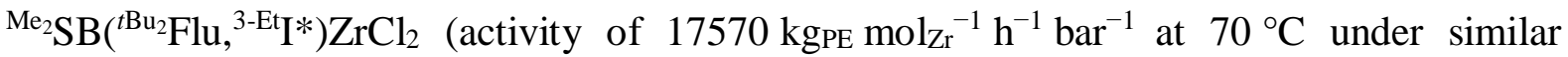
polymerisation conditions with $\left[\mathrm{Al}_{\mathrm{MAO}}\right]_{0} /[\mathrm{Zr}]_{0}$ of 2000).[27]

The molecular weights $\left(M_{\mathrm{w}}\right)$ of the polyethylenes produced using $\mathbf{1}$, determined by gel permeation chromatography (GPC), decreased as polymerisation temperature increased due to increased rates of termination rate relative to the propagation (Figure S15 and Table S2). The morphologies of the polymers were analysed by scanning electron microscopy (SEM), which showed the formation of very inhomogeneous and aggregated polymer particles with poorly defined structures (Figure S17). The poor morphologies of the polymers led to reactor fouling, which hindered efficient stirring and limits the large-scale applications of these species.

\subsection{Slurry-phase ethylene polymerisation}

In order to avoid reactor fouling caused by hot spots in homogeneous processes while maintaining the high polymerisation activities of the metallocenes, it is beneficial to immobilise the active catalytic components onto a heterogeneous support.[15] A 50:50 mixture of rac-and meso- ${ }^{\mathrm{Me}_{2}} \mathrm{SB}\left({ }^{3-\mathrm{Et}} \mathrm{I}^{*}\right) \mathrm{ZrCl}_{2}$ (1) was immobilised on solid polymethylaluminoxane (sMAO)[25, 28, 29] (1 $\mathbf{1}_{\text {SMAO }}$ ), MAO-modified silica (SSMAO)[10, 20, 30] (1 $\mathbf{1}_{\text {SSMAO }}$ ) and MAO-modified aqueous miscible organic (AMO) layered double hydroxide (LDHMAO)[22, 23, 39, 40]

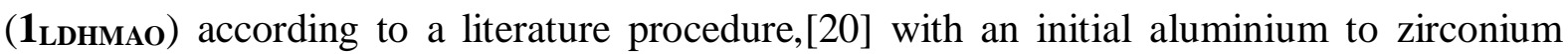
$\left(\left[\mathrm{Al} 1_{\mathrm{SMAO}}\right]_{0} /[\mathrm{Zr}]_{0}\right)$ loading of 200 .

The support and catalyst morphologies were analysed by SEM. The morphology of the sMAO support was shown to resemble aggregated, 'popcorn' shaped particles, which was retained after complex immobilisation, although slightly less aggregated (Figure S18). The spherical morphology of the SSMAO support also became less aggregated after immobilisation (Figure S19). The unique morphology of AMOLDH has small platelets forming loose flower-shape agglomerates, which have a more exposed surface compared to the densely 
stacked morphology of conventional LDHs (Figure S20).[24] LDHMAO also became less aggregated after complex immobilisation as a result of being dispersed in a hydrocarbon solvent (Figure S20).

Further characterisation of $\mathbf{1}_{\text {sMAO }}$ was achieved using solid-state NMR spectroscopy (SSNMR) (Figures S11-S13). The ${ }^{13} \mathrm{C}$ CP/MAS SSNMR spectrum shows a broad resonance at $-8 \mathrm{ppm}$ corresponding to the methyl groups of the support, in addition to resonances consistent with features of the immobilised complex. The ${ }^{29} \mathrm{Si}$ CP/MAS SSNMR spectrum shows a singlet resonance at $-13 \mathrm{ppm}$ corresponding to the silyl bridge of the complex. The presence of a slight shoulder indicates the presence of at least two Si species, which is consistent with the 50:50 mixture of rac-and meso-isomers immobilised on the support surface.

Slurry-phase ethylene polymerisation studies with $\mathbf{1}_{\text {SMAO }}, \mathbf{1}_{\text {SSMaO }}$ and $\mathbf{1}_{\text {LDHMaO }}$ were conducted in $150 \mathrm{~mL}$ ampoules with $50 \mathrm{~mL}$ hexane, $10 \mathrm{mg}$ pre-catalyst and 2 bar ethylene at $50-90{ }^{\circ} \mathrm{C}$ for 30 minutes with triisobutylaluminium (TiBA, $\mathrm{Al}\left(\mathrm{CH}_{2} \mathrm{CH}\left(\mathrm{CH}_{3}\right)_{2}\right)_{3}$ ) scavenger with $\left[\mathrm{Al}_{\text {scav }}\right]_{0} /[\mathrm{Zr}]_{0}$ of $1000 . \mathbf{1}_{\text {sSMaO }}$ and $\mathbf{1}_{\text {LDHMAO }}$ displayed approximately constant activities across the temperature range (272-383 and $102-125 \mathrm{~kg}_{\mathrm{PE}}$ mol $_{\mathrm{Zr}}{ }^{-1} \mathrm{~h}^{-1} \mathrm{bar}^{-1}$, respectively), while

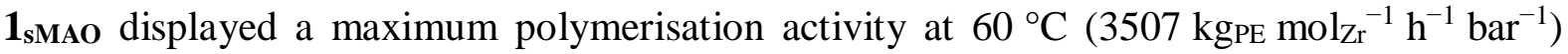
(Figure 2 and Tables S3-S5). 1 (activities of 3507,383 and $125 \mathrm{~kg}_{\mathrm{PE}} \mathrm{molzr}^{-1} \mathrm{~h}^{-1} \mathrm{bar}^{-1}$ respectively at $60{ }^{\circ} \mathrm{C}$ ), a trend also observed for ${ }^{\mathrm{Me}_{2}} \mathrm{SB}\left({ }^{t \mathrm{Bu}_{2}} \mathrm{Flu}, \mathrm{I}^{*}\right) \mathrm{ZrCl} 2$ and ${ }^{{ }^{\mathrm{Me}}}{ }_{2} \mathrm{SB}\left(\mathrm{Cp}^{\mathrm{R}}, \mathrm{I}^{*}\right) \mathrm{ZrX} 2$ complexes immobilised on the same three supports.[27, 30] This may be because some -OH groups remain on the surface of the $\mathrm{LDH}$ and $\mathrm{SiO}_{2}$ after calcination, which can hydrolyse $\mathrm{MAO}$ and reduce its performance as an activator.[41] Similar to the homogeneous polymerisation, 1sSMaO and 1LDHMAO display lower polymerisation activities than permethylated analogues, SSMAO-rac- ${ }^{\mathrm{Me}_{2}} \mathrm{SBI}^{*} \mathrm{ZrCl}_{2}$ and LDHMAO- $\left[\mathrm{rac}_{-}{ }^{\mathrm{Me}_{2}} \mathrm{SBI}^{*} \mathrm{ZrCl}_{2}\right]$, under similar polymerisation conditions (383, 108, 611 and $9657 \mathrm{~kg}_{\mathrm{PE}}$ molzr $^{-1} \mathrm{~h}^{-1} \mathrm{bar}^{-1}$ respectively at $70{ }^{\circ} \mathrm{C}$ ).[10] The activity of $\mathbf{1}_{\text {SSMAO }}$ is also significantly lower than SSMAO-rac-(EBI*) $\mathrm{ZrCl}_{2}\left(2647 \mathrm{~kg}_{\mathrm{PE}} \operatorname{mol}_{\mathrm{Zr}^{-1}} \mathrm{~h}^{-1} \mathrm{bar}^{-1}\right.$ at $\left.70{ }^{\circ} \mathrm{C}\right)$ under similar polymerisation conditions, [10] and SSMAO-rac-EBIZrCl ${ }_{2}$ (3111 $\mathrm{kg}_{\mathrm{PE}} \mathrm{mol}_{\mathrm{M}}{ }^{-1} \mathrm{~h}^{-1} \mathrm{bar}^{-1}$ with $\left[\mathrm{Al}{ }_{\mathrm{SSMAO}}\right]_{0} /[\mathrm{Zr}]_{0}=1700$ at $40{ }^{\circ} \mathrm{C}$ and 1.3 bar ethylene).[42] However, $\mathbf{1}_{\text {SSMaO }}$ shows ethylene polymerisation activities approximately 2.5 times higher than SSMAO- $\left(\mathrm{Cp}^{n \mathrm{Bu}}\right)_{2} \mathrm{ZrCl}_{2}$ (activity of $226 \mathrm{~kg}_{\mathrm{PE}} \mathrm{mol}_{\mathrm{Zr}}{ }^{-1} \mathrm{~h}^{-1} \mathrm{bar}^{-1}\left[\mathrm{Al}{ }_{\mathrm{SSMAO}}\right]_{0} /[\mathrm{Zr}]_{0}$ of 148 at $80{ }^{\circ} \mathrm{C}$ with 8 bar ethylene).[43] 


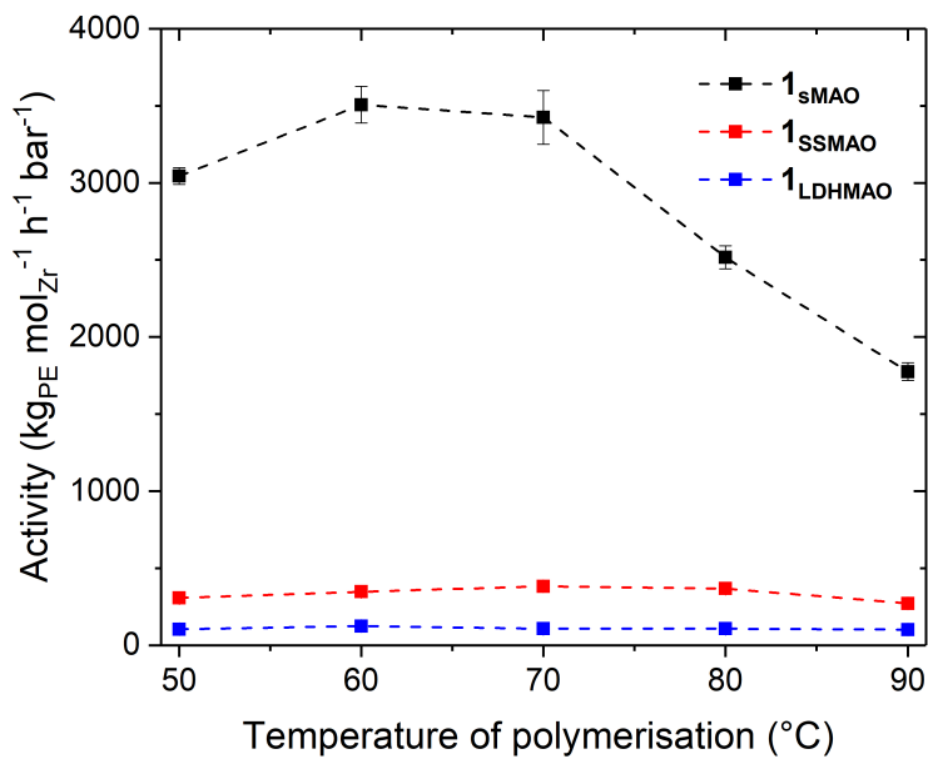

Figure 2. Slurry-phase ethylene polymerisation activity as a function of temperature of

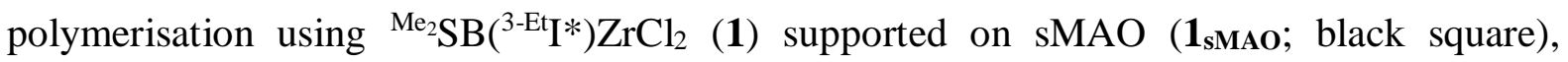
SSMAO (1 SSMao; red square) and LDHMAO (1 LDHMAO; blue square). Polymerisation conditions: ethylene ( 2 bar), pre-catalyst $(10 \mathrm{mg})$, hexane $(50 \mathrm{~mL}),\left[\mathrm{Al}_{\mathrm{sMAO}}\right]_{0} /[\mathrm{Zr}]_{0}=200$, TiBA (1000 eq.) and 30 minutes.

The molecular weights $\left(M_{\mathrm{w}}\right)$ of the polyethylenes produced using $\mathbf{1}_{\text {sMAO }}$ and $\mathbf{1}_{\text {SSMAO }}$ were analysed by GPC (Figures S21-S23). 1 $M_{\mathrm{w}}$ than $1_{\text {sMAO }} ; 787$ and $587 \mathrm{~kg} \mathrm{~mol}^{-1}$ respectively at $50{ }^{\circ} \mathrm{C}$ ), which is due to the presence of free TMA within MAO acting as a chain transfer agent.[28, 44] The polymers produced using 1sMAO show monomodal molecular weight distributions, although with wider dispersities than the polymers produced from homogeneous polymerisation using $1\left(M_{\mathrm{w}} / M_{\mathrm{n}}\right.$ of 4.4-6.1 and 2.32.5, respectively), suggesting the presence of two active sites resulting from the 50:50 mixture of rac-and meso-isomers. The polymers produced using $\mathbf{1}$ ssmao show an upper shoulder in the molecular weights distributions, accounting for the slightly larger dispersity values $\left(M_{\mathrm{w}} / M_{\mathrm{n}}\right.$ of 4.3-5.6). SEM images of the polyethylenes show that $\mathbf{1}_{\text {SSMAO }}$ and $\mathbf{1}_{\text {LDHMAO }}$ produced polyethylenes with very poor, undefined morphologies, while $\mathbf{1}_{\text {sMAO }}$ produced polyethylenes with uniform, 'popcorn' morphologies resembling that of the sMAO support (Figure 3). These differences in polymer morphologies are likely due to the templating effects of the solid support, whereby the morphology of the solid support is replicated in the final polymer with uniform particle size dependent on a high surface area, homogeneous distribution of catalytically active centres and ready availability of the innermost parts of the catalyst fragment to the incoming monomer.[15] Powder X-ray diffraction (PXRD) of the polyethylenes 
produced using $\mathbf{1}_{\text {sMAO }}$ showed Bragg reflections at $21.5^{\circ}$ and $24^{\circ}$ corresponding to (110) and (200) planes of high-density polyethylene (HDPE), respectively (Figure S30),[45] with the sharp nature of the spectrum confirming high crystallinity.[46]

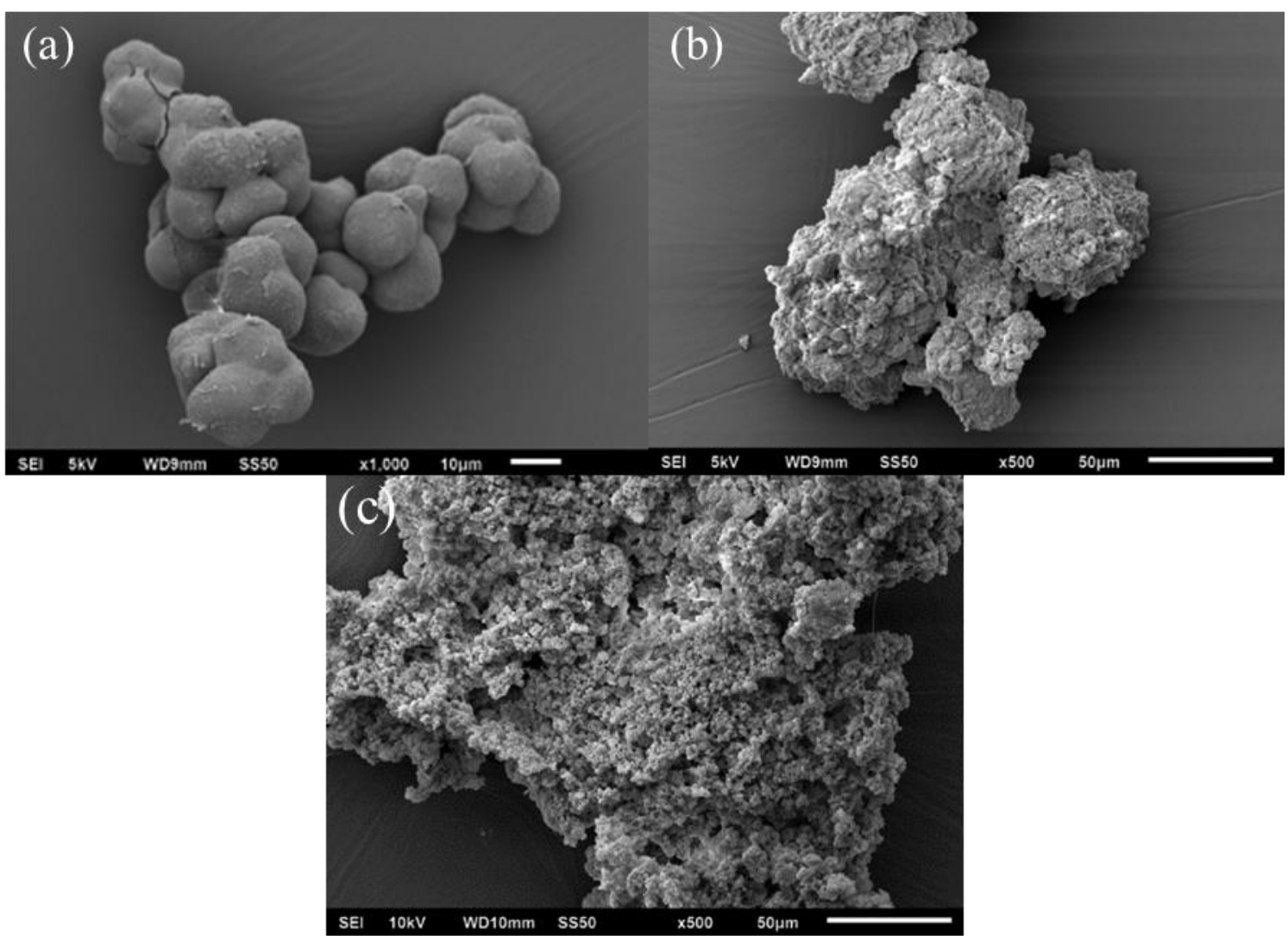

Figure 3. SEM images of the resulting polyethylenes of heterogeneous ethylene polymerisation using ${ }^{\mathrm{Me}_{2}} \mathrm{SB}\left({ }^{3-\mathrm{Et}} \mathrm{I}^{*}\right) \mathrm{ZrCl}_{2}$ (1) supported on (a) sMAO (1 $\mathbf{1}_{\text {sMAO}}$ ), (b) SSMAO (1SSMAo) and (c) LDHMAO (1 LDHMAo).

Due to the high polymerisation activity of $\mathbf{1}_{\text {SMAO }}$ compared to $\mathbf{1}_{\text {SSMaO }}$ and $\mathbf{1}_{\text {LDHMaO }}$, polymerisation conditions were optimised for this catalyst (scavenger, scavenger concentration and complex loading). All polymerisation reactions were conducted in $150 \mathrm{~mL}$ ampoules with $50 \mathrm{~mL}$ hexane, $10 \mathrm{mg}$ pre-catalyst and 2 bar ethylene at $60{ }^{\circ} \mathrm{C}$ for 30 minutes.

Trialkylaluminium reagents play an important role in ethylene polymerisation as impurity scavengers. They react with trace moisture or reactive functional groups present in the polymerisation setup and, hence, prevent decomposition of the metallocene.[47] However, they can also depress activity via the formation of dormant alkyl-bridged species, $\left[\mathrm{Cp}_{2} \mathrm{Zr}(\mu-\mathrm{R})(\mu-\mathrm{Me}) \mathrm{AlMe}_{2}\right]^{+}$, which block monomer coordination to the transition metal.[4850] In order to determine the ideal scavenger for polymerisation, slurry-phase ethylene 
polymerisation reactions were conducted using $\mathbf{1}_{\text {sMAO }}$ with four different scavengers (trimethylaluminium, TMA; triethylaluminium, TEA; triisobutylaluminium, TiBA; methylaluminoxane, MAO) with an initial scavenger to zirconium $\left(\left[\mathrm{Al}_{\text {scav }}\right]_{0} /[\mathrm{Zr}]_{0}\right)$ ratio of 1000 and a complex loading of $\left[\mathrm{Al}_{\mathrm{sMAO}}\right]_{0} /[\mathrm{Zr}]_{0}=200$.

TiBA was found to be the most effective scavenger followed by TEA and TMA (activities of 4533, 4390 and $3562 \mathrm{~kg}_{\mathrm{PE}}$ mol $_{\mathrm{Zr}}^{-1} \mathrm{~h}^{-1} \mathrm{bar}^{-1}$ respectively), which is consistent with the tendency of the trialkylaluminium regents to form the dormant alkyl-bridged species (TMA > TEA > TiBA) (Figure 4 and Table S6).[48-50] This trend in activity is also observed with sMAO- ${ }^{\mathrm{Me}_{2}} \mathrm{SB}\left(\mathrm{Cp}, \mathrm{I}^{*}\right) \mathrm{ZrCl}_{2}$ under similar polymerisation conditions; activities of 5144, 4649 and $3013 \mathrm{~kg}_{\mathrm{PE}} \mathrm{molzr}^{-1} \mathrm{~h}^{-1} \mathrm{bar}^{-1}$ for polymerisation using TiBA, TEA and TMA respectively.[32] Using MAO as the impurity scavenger caused leaching of the metallocene complex into the solution,[51] which initiated homogeneous polymerisation, disrupting stirring and leading to reduced activity (2393 $\mathrm{kg}_{\mathrm{PE}}$ molzr$\left.^{-1} \mathrm{~h}^{-1} \mathrm{bar}^{-1}\right)$. The molecular weights $\left(M_{\mathrm{w}}\right)$ of the polyethylenes are consistent with the trends in activity $\left(M_{\mathrm{w}}\right.$ of 131,185 and $356 \mathrm{~kg} \mathrm{~mol}^{-1}$ for TMA, TEA and TiBA respectively), with the higher $M_{\mathrm{w}}$ of the polymers produced using MAO ( $M_{\mathrm{w}}$ of $\left.451 \mathrm{~kg} \mathrm{~mol}^{-1}\right)$ caused by homogeneous polymerisation (Figures 4 and S24). The lower molecular weights of the polymers produced using TMA and TEA compared to TiBA and MAO can be attributed to the size of the alkyl group; the smaller the alkyl group of aluminium scavenger, the faster the rate of chain transfer and the lower polymer molecular weights. $[52,53]$ Overall, TiBA is the best performing impurity scavenger for this system.

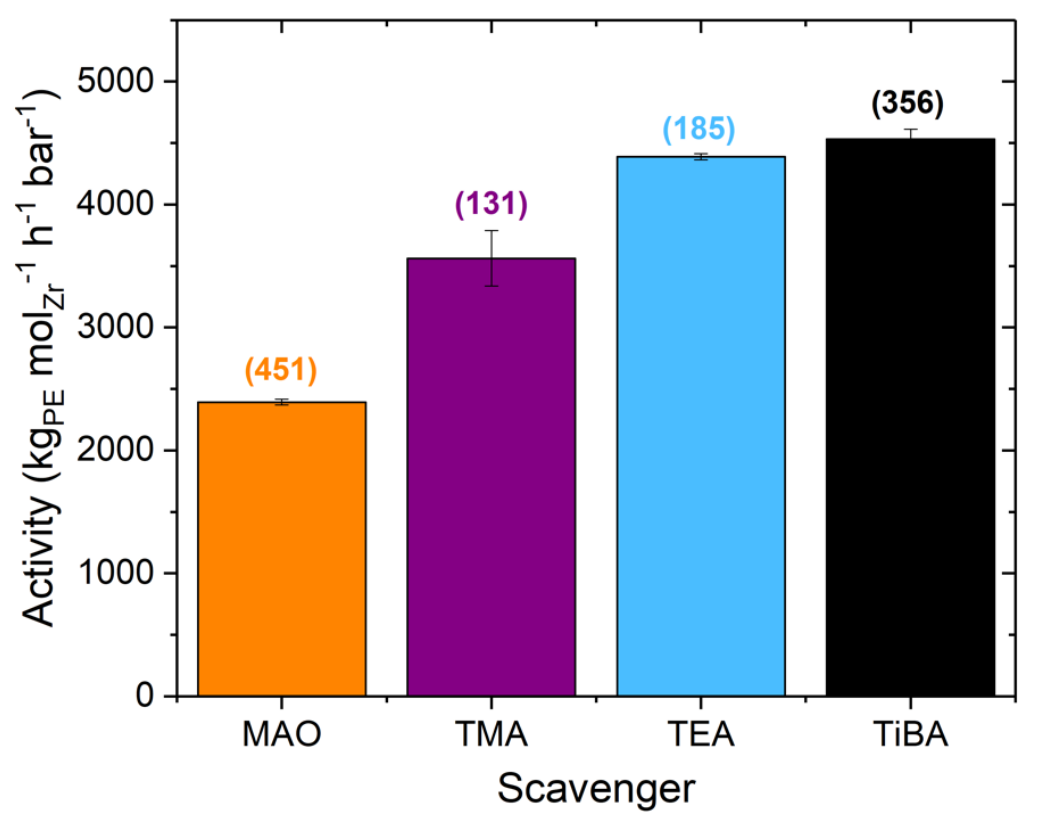


Figure 4. Slurry-phase ethylene polymerisation activity using ${ }^{{ }^{\mathrm{e}}}{ }_{2} \mathrm{SB}\left({ }^{3-\mathrm{Et}} \mathrm{I} *\right) \mathrm{ZrCl}_{2}$ supported on sMAO (1 $\mathbf{1}_{\text {sMAO) }}$ ) with MAO (orange), TMA (purple), TEA (teal) and TiBA (black) scavengers. $M_{\mathrm{w}}$ in parenthesis $\left(\mathrm{kg} \mathrm{mol}^{-1}\right)$. Polymerisation conditions: ethylene (2 bar), pre-catalyst (10 $\left.\mathrm{mg}\right)$, hexane $(50 \mathrm{~mL}),\left[\mathrm{Al}_{\mathrm{sMAO}}\right]_{0} /[\mathrm{Zr}]_{0}=200,\left[\mathrm{Al}_{\mathrm{scav}}\right]_{0} /[\mathrm{Zr}]_{0}=1000,60{ }^{\circ} \mathrm{C}$ and 30 minutes.

To balance between the opposing effects of TiBA, such as the formation of dormant alkyl-bridged species, with the activity enhancement due to its scavenging properties, optimisation of catalyst activity with respect to TiBA loading was investigated. Slurry-phase ethylene polymerisation reactions were conducted using $\mathbf{1}_{\text {sMAO }}$ with $\left[\mathrm{Al}_{\mathrm{TiBA}} .\right]_{0} /[\mathrm{Zr}]_{0}$ of 100 2000 and $\left[\mathrm{Al}_{\mathrm{SMAO}}\right]_{0} /[\mathrm{Zr}]_{0}$ of 200 . [ $\left[\mathrm{Al}_{\mathrm{TiBA}} .\right]_{0} /[\mathrm{Zr}]_{0}$ of 1000 was found to be the optimal concentration to remove impurities from the system without causing significant decreases in polymerisation activity; maximum activity of $4533 \mathrm{~kg}_{\mathrm{PE}}$ molzr$^{-1} \mathrm{~h}^{-1} \mathrm{bar}^{-1}$ (Figure 5 and Table S6). In general, the $M_{\mathrm{w}}$ of the resulting polyethylenes decreased with increasing TiBA concentration (from 487 to $332 \mathrm{~kg} \mathrm{~mol}^{-1}$ with $\left[\mathrm{Al}_{\mathrm{TiBA}}\right]_{0} /[\mathrm{Zr}]_{0}$ of 100 to 1500 ), which is likely due to TiBA acting as a chain transfer agent at higher concentrations.[54]

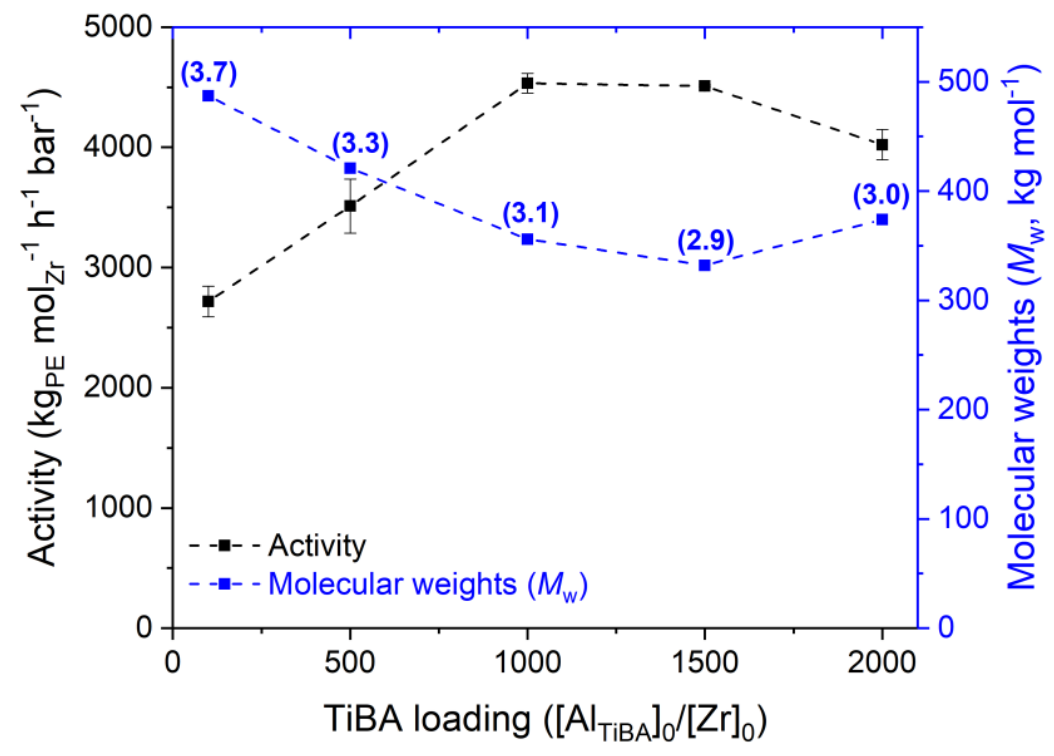

Figure 5. Slurry-phase ethylene polymerisation activity (black square) and molecular weights $\left.\left(M_{\mathrm{w}} \text {; blue square) as a function of TiBA loading ([Al } \mathrm{AlBBA}_{\mathrm{TiB}}\right]_{0} /[\mathrm{Zr}]_{0}\right)$ using ${ }^{\mathrm{Me}_{2}} \mathrm{SB}\left({ }^{3-\mathrm{Et}} \mathrm{I}\right) \mathrm{ZrCl}_{2}$ supported on sMAO (1 $\mathbf{1}_{\text {sMAo)}) .} M_{\mathrm{w}} / M_{\mathrm{n}}$ in parenthesis. Polymerisation conditions: ethylene (2 bar), pre-catalyst $(10 \mathrm{mg})$, hexane $(50 \mathrm{~mL}),\left[\mathrm{Al}_{\mathrm{sMAO}}\right]_{0} /[\mathrm{Zr}]_{0}=200,60{ }^{\circ} \mathrm{C}$ and 30 minutes.

The complex loading $\left(\left[\mathrm{Al}_{\mathrm{SMAO}}\right]_{0} /[\mathrm{Zr}]_{0}\right)$, inferring to the surface concentration of immobilised

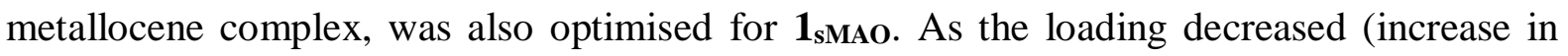
$\left[\mathrm{Al}_{\mathrm{sMAO}}\right]_{0} /[\mathrm{Zr}]_{0}$ ratio from 100 to 300$)$, the ethylene polymerisation activity increased due to 
the easier access to the monomer by each metallocene complex (Figure S16 and Table S7). Severn and Chadwick also observed higher polymerisation activities with lower catalyst loadings using $\mathrm{Cp}_{2} \mathrm{TiCl}_{2}$ and $\left.{ }^{\mathrm{Me}_{2}} \mathrm{Si}^{t{ }^{t B u}}{ }^{\mathrm{N}}, \mathrm{Cp}^{*}\right) \mathrm{TiCl}_{2}$ immobilised on $\mathrm{MgCl}_{2}\left(\mathrm{Al}_{0.24}\right) \mathrm{Et}_{2.30}(\mathrm{OEt})_{0.70}$; activities of 301 and $692 \mathrm{~kg}_{\mathrm{PE}} \mathrm{mol}_{\mathrm{Ti}}{ }^{-1} \mathrm{~h}^{-1} \mathrm{bar}^{-1}$ with catalyst loadings of 100 and $5 \mu \mathrm{mol} \mathrm{g}{ }^{-1}$ respectively (50 ${ }^{\circ} \mathrm{C}$ and 10 bar ethylene).[55] However, when productivity is considered, there is an optimal $\left[\mathrm{Al}_{\mathrm{SMAO}}\right]_{0} /[\mathrm{Zr}]_{0}$ ratio of 200 , which maximises the polymerisation capability per gram of the catalyst $\left(0.329 \mathrm{~kg}_{\mathrm{PE}} \mathrm{g}_{\mathrm{cat}}{ }^{-1} \mathrm{~h}^{-1} \mathrm{bar}^{-1}\right)$.

Following this, slurry-phase ethylene polymerisation using varied loadings of $\mathbf{1}_{\text {sMAO }}(5-20 \mathrm{mg})$ were carried out with $\left[\mathrm{Al}_{\mathrm{SMAO}}\right]_{0} /[\mathrm{Zr}]_{0}$ of 200 . As expected, a catalyst loading of $20 \mathrm{mg}$ resulted in lower activities than catalyst loadings of $10 \mathrm{mg}$ (2809 and $4533 \mathrm{~kg}_{\mathrm{PE}} \mathrm{molzr}^{-1} \mathrm{~h}^{-1} \mathrm{bar}^{-1}$, respectively) due to the physical limitations of the reactor. However, a catalyst loading of $5 \mathrm{mg}$ surprisingly also yielded a slightly lower activity ( $\left.3747 \mathrm{~kg}_{\mathrm{PE}} \mathrm{mol}_{\mathrm{Zr}}{ }^{-1} \mathrm{~h}^{-1} \mathrm{bar}^{-1}\right)$. To study the effect of increased reaction volume, polymerisations were conducted in a $500 \mathrm{~mL}$ ampoule with a catalyst loading of $10 \mathrm{mg}, 250 \mathrm{~mL}$ hexane, 2 bar ethylene and $\left[\mathrm{Al}_{\mathrm{TiBA}}\right]_{0} /[\mathrm{Zr}]_{0}$ of 1000 at $60{ }^{\circ} \mathrm{C}$ for 30 minutes. Typically, an increase in activity with an increase in solvent volume is observed due to decreases in gas-liquid mass transfer limitations.[56] However, for $\mathbf{1}_{\text {sMAO }}$, a lower polymerisation activity was observed on the larger scale (activity of $\left.3812 \mathrm{~kg}_{\mathrm{PE}} \mathrm{molzr}^{-1} \mathrm{~h}^{-1} \mathrm{bar}^{-1}\right)$. This is in contrast to sMAO- ${ }^{{ }^{-}}{ }_{2} \mathrm{SB}\left(\mathrm{Cp}, \mathrm{I}^{*}\right) \mathrm{ZrCl}_{2}$ under similar condition, where an approximate 2 -fold increase in activity was observed using $250 \mathrm{~mL}$ solvent compared to $50 \mathrm{~mL}$.[30] It is therefore concluded that although the physical saturation of the reactor can lower the activity, for this system there is a minimum concentration of the catalyst loading per reaction volume required in order for ethylene polymerisation to function optimally. The lower polymerisation activity on the larger scale could also be due to the lower scavenger concentration; the larger volume of solvent is likely to contain increased quantities of impurities, which may lead to catalyst deactivation and decreases in polymerisation activity.

Using the optimised conditions, slurry-phase ethylene polymerisation was conducted using four different sMAO supported complexes. A 50:50 mixture of rac- and

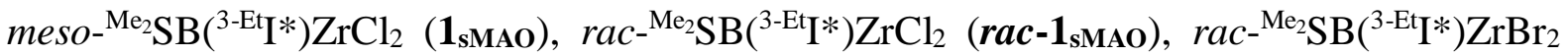
$\left(\right.$ rac $\left.-2_{\text {sMAO }}\right)$ and a 75:25 mixture of rac- and meso- ${ }^{\mathrm{Me}}{ }_{2} \mathrm{SB}\left({ }^{3-\mathrm{Et}} \mathrm{I}^{*}\right) \mathrm{Zr}\left(\mathrm{CH}_{2} \mathrm{Ph}\right)_{2}(3)$ were studied in $150 \mathrm{~mL}$ ampoules with $10 \mathrm{mg}$ pre-catalyst, $\left[\mathrm{Al}_{\mathrm{TiBA}}\right]_{0} /[\mathrm{Zr}]_{0}=1000,2$ bar ethylene, $\left[\mathrm{Al}_{\mathrm{SMAO}}\right]_{0} /[\mathrm{Zr}]_{0}=200$ and $50 \mathrm{~mL}$ hexane for 30 minutes at $50-90{ }^{\circ} \mathrm{C}$. 
$\mathbf{1}_{\text {SMAO, rac-1 }}$ SMAO and rac-2 $\mathbf{s M A O}$ showed very similar polymerisation activities across the temperature range $\left(3507,3312\right.$ and $3971 \mathrm{~kg}_{\mathrm{PE}} \mathrm{molZr}^{-1} \mathrm{~h}^{-1} \mathrm{bar}^{-1}$ respectively at $\left.60{ }^{\circ} \mathrm{C}\right)$, which is consistent with the trend observed for ${ }^{\mathrm{Me}_{2}} \mathrm{SB}\left(\mathrm{Cp}, \mathrm{I}^{*}\right) \mathrm{ZrX}_{2}(\mathrm{X}=\mathrm{Cl}$ and $\mathrm{Br}$ ) (Figure 6 and Tables S3, S8-S10).[30] 3 3Mao consistently showed higher polymerisation activities (4832 $\mathrm{kg}_{\mathrm{PE}}$ molzr $^{-1} \mathrm{~h}^{-1} \mathrm{bar}^{-1}$ at $60{ }^{\circ} \mathrm{C}$ ), which may be because larger, more flexible benzyl ligands can weaken the interaction between the cationic catalyst and anionic counterion, allowing more space for ethylene monomers to coordinate (Figure 6).[57] $\mathbf{3}_{\text {sMAO also does not }}$ need to be alkylated, which likely leads to faster formation of the active species compared to $\mathbf{1}_{\text {SMAO, }}$ rac $-\mathbf{1}_{\text {SMAO }}$ and $r a c-2_{\text {SMAO, }}$, therefore leading to increases in the polymerisation activity.[58, 59] For solution-phase polymerisation using metallocene catalysts and MAO activator, it is known that chlorination of MAO can be detrimental for catalyst activation.[60] Similar effects may occur for sMAO and may reduce the polymerisation activities of $\mathbf{1}_{\text {sMAO }}$ and $r a c-1_{\text {sMAO. }}$

An increase in ethylene polymerisation activity on moving from halide to alkyl initiation groups has also been observed for sMAO-meso-EBI* $\mathrm{ZrX}_{2}$ and $\mathrm{sMAO}-{ }^{\mathrm{Me}_{2}} \mathrm{SB}\left({ }^{\mathrm{tBu}} \mathrm{N}, \mathrm{I}^{*}\right) \mathrm{TiX}_{2}$, where $\mathrm{X}=\mathrm{CH}_{2} \mathrm{Ph}$ displayed optimum activities approximately double $\mathrm{X}=\mathrm{Cl}$; activities of 5179 and $2246 \mathrm{~kg}_{\mathrm{PE}} \mathrm{mol}^{-1} \mathrm{~h}^{-1} \mathrm{bar}^{-1}$ for sMAO-meso-EBI* $\mathrm{ZrX}_{2},[25]$ and activities of 5793 and $3602 \mathrm{~kg}_{\mathrm{PE}} \mathrm{mol}^{-1} \mathrm{~h}^{-1} \mathrm{bar}^{-1}$ sMAO- ${ }^{{ }^{\mathrm{M}}}{ }_{2} \mathrm{SB}\left({ }^{\mathrm{BBu}} \mathrm{N}, \mathrm{I}^{*}\right) \mathrm{TiX}_{2}$.[31] The maximum activity of $\mathbf{3}_{\mathrm{sMAO}}$ is similar to that of meso-EBI* $\mathrm{Zr}\left(\mathrm{CH}_{2} \mathrm{Ph}\right)_{2} ; 4832$ and $5179 \mathrm{~kg}_{\mathrm{PE}}$ molzr $^{-1} \mathrm{~h}^{-1} \mathrm{bar}^{-1}$ respectively at $60{ }^{\circ} \mathrm{C}\left([\mathrm{Zr}]_{0} /\left[\mathrm{Al}_{\mathrm{sMAO}}\right]_{0}\right.$ of 300$) \cdot[25]$

A 50:50 mixture of rac- and meso- $\left.{ }^{\mathrm{Me}_{2}} \mathrm{SB}^{3-\mathrm{Et}^{*}}\right) \mathrm{ZrCl}_{2}\left(\mathbf{1}_{\text {sMAO }}\right)$ was found to be slightly more active than the pure $r a c$-isomer ( $\mathbf{r a c}$-1 $\left.\mathbf{1}_{\mathbf{S M A O}}\right)$, implying that both isomers have similar activities. This is in contrast to the $\mathrm{EBI} * \mathrm{ZrCl}_{2}$ system, where rac-EBI* $\mathrm{ZrCl}_{2}$ was found to have higher ethylene polymerisation activities than more sterically crowded meso-EBI* $\mathrm{ZrCl}_{2}$; activities of 5006 and $1331 \mathrm{~kg}_{\mathrm{PE}} \operatorname{mol}_{\mathrm{Zr}}{ }^{-1} \mathrm{~h}^{-1} \mathrm{bar}^{-1}$ when supported on sMAO with $\left[\mathrm{Al}_{\mathrm{SMAO}}\right]_{0} /[\mathrm{Zr}]_{0}$ of 200 and 300 respectively.[25] When directly compared to these catalysts, $r a c-\mathbf{1}_{\text {sMAO }}$ shows lower polymerisation activities than sMAO-rac-EBI* $\mathrm{ZrCl}_{2}\left(3144\right.$ and $5365 \mathrm{~kg}_{\mathrm{PE}} \mathrm{mol}_{\mathrm{Zr}}{ }^{-1} \mathrm{~h}^{-1} \mathrm{bar}^{-1}$ respectively at $\left.50{ }^{\circ} \mathrm{C}\right)$.[25] However, a 50:50 mixture of the rac- and meso-isomers (1 $\left.\mathbf{1}_{\text {sMAO}}\right)$ shows higher polymerisation activities than sMAO-meso-EBI* $\mathrm{ZrCl}_{2} \quad(3425$ and $2246 \mathrm{~kg}_{\mathrm{PE}} \mathrm{molzr}^{-1} \mathrm{~h}^{-1} \mathrm{bar}^{-1}$ respectively at $\left.70{ }^{\circ} \mathrm{C}\right),[25]$ but lower activities than sMAO-rac-EBI* $\mathrm{ZrCl}_{2}$ (3044 and $5365 \mathrm{~kg}_{\mathrm{PE}}$ molzr $^{-1} \mathrm{~h}^{-1} \mathrm{bar}^{-1}$ respectively at $50{ }^{\circ} \mathrm{C}$ ).[25] 


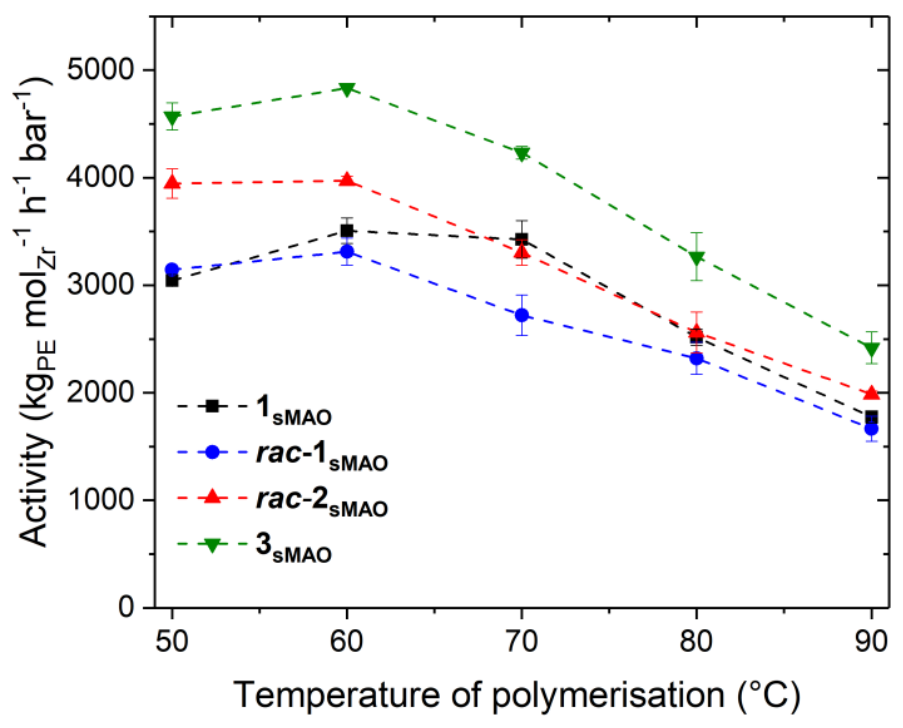

Figure 6. Slurry-phase ethylene polymerisation activity as a function of temperature of

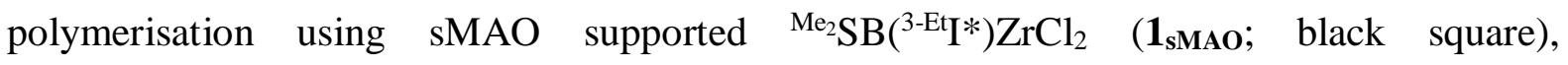
rac $-{ }^{\mathrm{Me}_{2}} \mathrm{SB}\left({ }^{3-\mathrm{Et}} \mathrm{I}^{*}\right) \mathrm{ZrCl}_{2}$ ( rac $-\mathbf{1}_{\mathrm{SMAO}}$; blue circle), rac- $\left.{ }^{\mathrm{Me}_{2}} \mathrm{SB}^{3-\mathrm{Et}}{ }^{*}\right) \mathrm{ZrBr}_{2}$ (2 $\mathbf{2}_{\mathbf{S M A O}}$; red triangle) and ${ }^{\mathrm{Me}_{2}} \mathrm{SB}\left({ }^{3-\mathrm{Et}} \mathrm{I}^{*}\right) \mathrm{Zr}\left(\mathrm{CH}_{2} \mathrm{Ph}\right)_{2} \quad\left(\mathbf{3}_{\mathrm{sMAO}}\right.$; green down triangle). Polymerisation conditions: ethylene ( 2 bar), pre-catalyst $(10 \mathrm{mg})$, hexane $(50 \mathrm{~mL}),\left[\mathrm{Al}_{\mathrm{sMAO}}\right]_{0} /[\mathrm{Zr}]_{0}=200$, TiBA $(1000 \mathrm{eq}$. and 30 minutes.

$\mathbf{1}_{\text {SMAO, }} \boldsymbol{r a c}$ - $\mathbf{1}_{\text {SMAO }}$, rac $-\mathbf{2}_{\text {SMAO }}$ and $\mathbf{3}_{\text {SMAO }}$ all showed maximum activities at $60{ }^{\circ} \mathrm{C}(3507,3312$, 3971 and $4832 \mathrm{~kg}_{\mathrm{PE}}$ mol $_{\mathrm{Zr}}^{-1} \mathrm{~h}^{-1} \mathrm{bar}^{-1}$ respectively). The decreases in activity above $60{ }^{\circ} \mathrm{C}$ suggests deactivation or decomposition at elevated temperature, or that polymerisation activity is significantly affected by the decrease in the solubility of ethylene in hexane at higher temperatures.[61]

The molecular weights of the polyethylenes were characterised by GPC. All the catalysts showed modest molecular weights, which decreased as polymerisation temperature increased

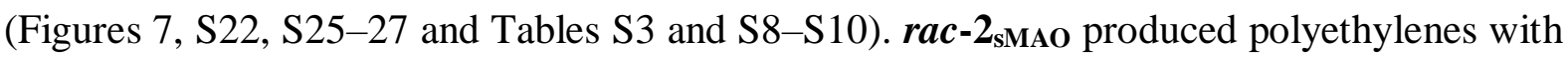
lower molecular weights $\left(M_{\mathrm{w}}\right)$ than $\mathbf{r a c}-\mathbf{1}_{\mathrm{sMAO}}$, which may be due to its higher polymerisation activity $\left(M_{\mathrm{w}}\right.$ of 326 and $477 \mathrm{~kg} \mathrm{~mol}^{-1}$ at $\left.50{ }^{\circ} \mathrm{C}\right)$. The polymers produced using rac $-\mathbf{1}_{\text {sMAO, }}$, rac $-2_{\text {SMAO }}$ and $3_{\text {SMAO }}$ show relatively narrow dispersities with $M_{\mathrm{w}} / M_{\mathrm{n}}$ of $4.1-4.9,2.7-3.4$ and 3.0-3.2 respectively. The polymers produced using $\mathbf{1}_{\text {sMaO }}$ show slightly larger dispersities $\left(M_{\mathrm{w}} / M_{\mathrm{n}}\right.$ of 4.4-6.1), which could be due to the 50:50 mix of rac-and meso-isomers (Table S3) The larger than expected dispersity values of these catalysts $\left(M_{\mathrm{w}} / M_{\mathrm{n}}>3\right)$ may be due to gas-to-liquid mass transfer limitations, which are likely present due to the high activities of the catalysts and the relatively small scale of the polymerisations $(50 \mathrm{~mL})$. Gas-to-liquid mass 
transfer limitations are known to affect polymer properties, with higher molecular weight distributions shown to arise in the presence of gas-to-liquid mass transfer limitations for some systems.[62]

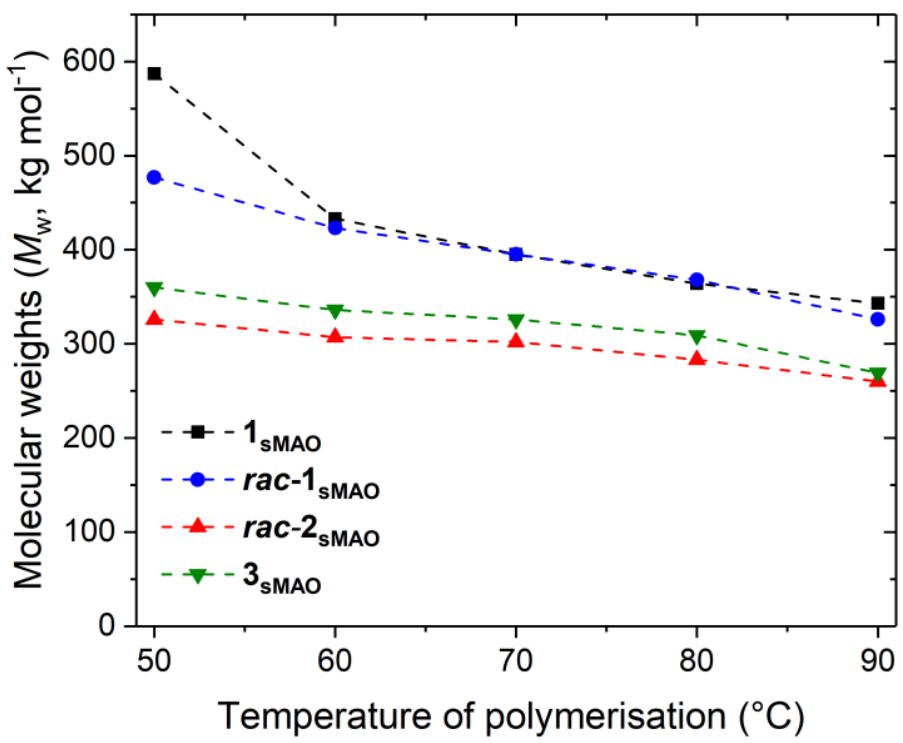

Figure 7. Molecular weights $\left(M_{\mathrm{w}}\right)$ as a function of temperature of polymerisation using sMAO supported ${ }^{\mathrm{Me}_{2}} \mathrm{SB}\left({ }^{3-\mathrm{Et}} \mathrm{I}^{*}\right) \mathrm{ZrCl}_{2}$ (1 $\mathbf{1}_{\text {sMAO }}$; black square), rac- ${ }^{\mathrm{Me}_{2}} \mathrm{SB}\left({ }^{3-\mathrm{Et}} \mathrm{I}^{*}\right) \mathrm{ZrCl}_{2}$ (rac $-\mathbf{1}_{\text {sMAO }}$; blue circle), $\mathrm{rac}_{-}{ }^{\mathrm{Me}_{2}} \mathrm{SB}\left({ }^{3-\mathrm{Et}} \mathrm{I}^{*}\right) \mathrm{ZrBr}_{2}\left(\mathbf{2}_{\mathrm{sMAO}}\right.$; red triangle) and ${ }^{\mathrm{Me}_{2}} \mathrm{SB}\left({ }^{3-\mathrm{Et}} \mathrm{I}^{*}\right) \mathrm{Zr}\left(\mathrm{CH}_{2} \mathrm{Ph}\right)_{2}\left(\mathbf{3}_{\mathrm{sMAO}}\right.$; green down triangle). Polymerisation conditions: ethylene ( 2 bar), pre-catalyst (10 mg), hexane $(50 \mathrm{~mL}),\left[\mathrm{Al}_{\mathrm{sMAO}}\right]_{0} /[\mathrm{Zr}]_{0}=200, \mathrm{TiBA}(1000$ eq. $)$ and 30 minutes.

\section{$2.3 \mathrm{H}_{2}$ as a chain transfer agent}

Dihydrogen $\left(\mathrm{H}_{2}\right)$ is a common chain transfer agent for $\alpha$-olefins polymerisation using metallocene catalysts as it can decrease and control polymer molecular weights.[63, 64] rac- ${ }^{\mathrm{Me}_{2}} \mathrm{SB}\left({ }^{3-\mathrm{Et}} \mathrm{I}^{*}\right) \mathrm{ZrCl}_{2}$ (rac-1 $\left.\mathbf{1}_{\mathrm{SMAO}}\right)$ was tested for its response to $\mathrm{H}_{2}$ in a high-throughput screening system, which makes use of miniaturised, automated, parallel reaction set-ups to allow for reduced time in the screening of different conditions.[65, 66] Polymerisations were conducted in a parallel pressure reactor (PPR) in $23 \mathrm{~mL}$ cells with $5 \mathrm{~mL}$ heptane, $10 \mu \mathrm{mol}$ TiBA scavenger, $0.30-0.40 \mathrm{mg}$ rac $-\mathbf{1}_{\text {sMAO }}$ with $\left[\mathrm{Al}_{\mathrm{sMAO}}\right]_{0} /[\mathrm{Zr}]_{0}$ of $200,8.3$ bar ethylene and 0 , $0.8 \%$ ( 0.07 bar) or $1.6 \%\left(0.13\right.$ bar) $\mathrm{H}_{2}$ supplied by a mixed $\mathrm{H}_{2} / \mathrm{N}_{2}$ feed. Reactions were run at $80{ }^{\circ} \mathrm{C}$ for 1 hour or until 8.3 bar ethylene uptake was reached. Prior to polymerisation, the $\mathrm{Zr}$ content of the catalyst was measured by inductively coupled plasma (ICP) analysis to be $0.61 \mathrm{wt} \%$, which is in good agreement with the expected value of $0.64 \mathrm{wt} \%$. 
The in-situ ethylene uptake rates reflect the rate of polymerisation (Figure 8). For all polymerisation runs the initial ethylene uptake rates are very high, which then sharply decline to low but stable rates. The ethylene uptake rates and polymerisation activities were observed to decrease as the amount of $\mathrm{H}_{2}$ in the system increased; activities of 2100, 1100 and $640 \mathrm{~kg}_{\mathrm{PE}} \mathrm{molzr}^{-1} \mathrm{~h}^{-1} \mathrm{bar}^{-1}$ with $0,0.8$ and $1.6 \% \mathrm{H}_{2}$. This effect has also been observed for sMAO- ${ }^{\mathrm{Me}_{2}} \mathrm{SB}\left(\mathrm{Cp}^{\mathrm{R}}, \mathrm{I}^{*}\right) \mathrm{ZrX} \mathrm{X}_{2}$ and $\mathrm{sMAO}-{ }^{\mathrm{Me}_{2}} \mathrm{SB}\left({ }^{\mathrm{R}} \mathrm{N},{ }^{3-\mathrm{R}} \mathrm{I}^{*}\right) \mathrm{TiX}_{2}$ catalysts in the same system,[67, 68] and is likely due to formation of a metal hydride termination product, which requires reactivation by insertion of ethylene. This leads to reductions in polymerisation activity as the rate of insertion of ethylene into $\mathrm{Zr}-\mathrm{H}$ is much slower than the rate of insertion into $\mathrm{Zr}-\mathrm{Me}$.[6972]

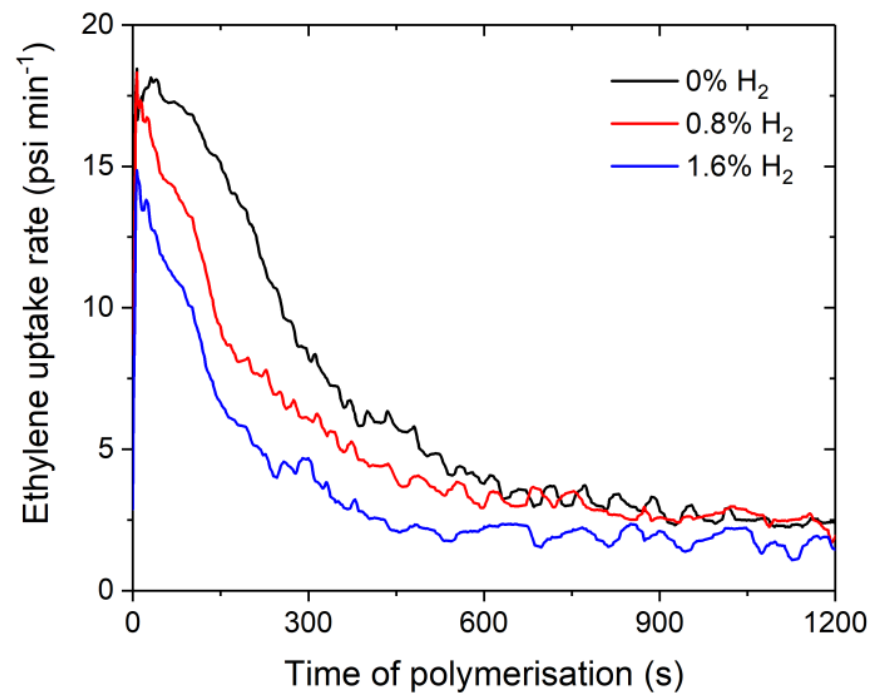

Figure 8. Slurry-phase polymerisation ethylene uptake rate as a function of time of polymerisation using sMAO supported $\mathrm{rac}_{-}{ }^{\mathrm{Me}_{2}} \mathrm{SB}\left({ }^{3-\mathrm{Et}} \mathrm{I}^{*}\right) \mathrm{ZrCl}_{2}$ (rac $\left.-\mathbf{1}_{\text {sMAO }}\right)$ with 0 (black), 0.8 (red) and $1.6 \% \mathrm{H}_{2}$ (blue). Polymerisation conditions: $\left[\mathrm{Al}_{\mathrm{sMAO}}\right]_{0} /[\mathrm{Zr}]_{0}=200$, TiBA $(10 \mu \mathrm{mol})$, ethylene $\left(8.3\right.$ bar), pre-catalyst $(0.05 \mathrm{mg})$, heptane $(5 \mathrm{~mL})$ and $80^{\circ} \mathrm{C}$. Reactions quenched at 8.3 bar ethylene uptake or after 1 hour.

As $\mathrm{H}_{2}$ acts as a chain transfer agent, increases in $\mathrm{H}_{2}$ partial pressure significantly lowers the molecular weights $\left(M_{\mathrm{w}}\right)$ of the resulting polyethylenes; 1009,37 and $20 \mathrm{~kg} \mathrm{~mol}^{-1}$ with $0,0.8$ and $1.6 \% \mathrm{H}_{2}$ (Figure S28). The decreases in $M_{\mathrm{w}}$ are similar to those observed using sMAO- $\left.{ }^{\mathrm{Me}_{2}} \mathrm{SB}^{\mathrm{tBu}} \mathrm{N}, \mathrm{I}^{*}\right) \mathrm{TiCl}_{2} \quad\left(M_{\mathrm{w}}\right.$ of 2700 and $41 \mathrm{~kg} \mathrm{~mol}^{-1}$ with 0 and $1.6 \% \mathrm{H}_{2}$ respectively).[68] $M_{\mathrm{w}} / M_{\mathrm{n}}$ decreases slightly in the presence of $\mathrm{H}_{2}(6.6,2.8$ and 3.2 with $0,0.8$ and $1.6 \% \mathrm{H}_{2}$ respectively), which suggests that one termination process dominates. $\mathrm{As}_{2}$ is a strong chain transfer agent,[73] it is likely that termination primarily occurs by chain transfer 
to $\mathrm{H}_{2}$ and other termination pathways (for example, termination by chain transfer to aluminium) are suppressed.

\subsection{Ethylene/1-hexene copolymerisation}

rac $-{ }^{\mathrm{Me}_{2}} \mathrm{SB}\left({ }^{3-\mathrm{Et}} \mathrm{I}^{*}\right) \mathrm{ZrCl}_{2}$ (rac $\left.-\mathbf{1}_{\mathrm{SMAO}}\right)$ was also studied for its ethylene/1-hexene copolymerisation performance. High-throughput polymerisations were conducted in a PPR at $80{ }^{\circ} \mathrm{C}$ with $8.3 \mathrm{bar}$ ethylene, $5 \mathrm{~mL}$ heptane, $10 \mu \mathrm{mol}$ TiBA scavenger, $0.30-0.40 \mathrm{mg}$ pre-catalyst $\left(\left[\mathrm{Al}_{\mathrm{sMAO}}\right]_{0} /[\mathrm{Zr}]_{0}\right.$ $=200$ ) and 0,125 or $250 \mu \mathrm{L}$ 1-hexene for 1 hour or until 5.5 bar ethylene uptake was reached.

The ethylene uptake rate profiles show that the catalyst becomes more active as the amount of co-monomer in the system increases; activities of 2100, 2100 and $4000 \mathrm{~kg}_{\mathrm{PE}} \mathrm{mol}_{\mathrm{Zr}}^{-1} \mathrm{~h}^{-1} \mathrm{bar}^{-1}$ with 0,125 and $250 \mu \mathrm{L}$ 1-hexene respectively (Figure 9). This is due to the comonomer effect, where incorporation of $\alpha$-olefins decreases polymer crystallinity, which leads to an increase in polymer solubility and more easily accessible active sites.[74-76] It has also been proposed that the catalytically active sites may coordinate one ethylene and one 1-hexene monomer,[77] with the more electron rich $\alpha$-olefin stabilising the active site and 'triggering' the insertion of ethylene, leading to an enhancement in activity.[78-80] Additionally, ethylene solubility is enhanced by up to $10 \%$ on the addition of 1-hexene, which could contribute to increases in polymerisation activity.[81] The rate enhancing effect of 1-hexene has also been observed in the solution phase for ethylene/1-hexene copolymerisation using unmethylated $\mathrm{rac}-\mathrm{EBIZrCl}_{2}$, where activity increased by $30 \%$ on the introduction of $0.5 \mathrm{~mol} \mathrm{~L}^{-1} 1$-hexene.[82]

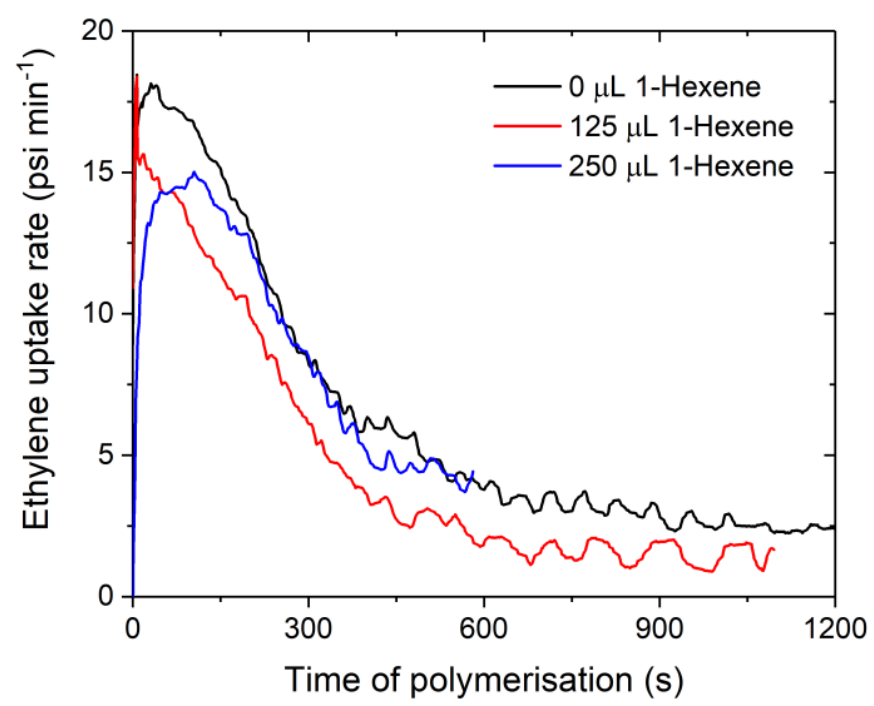

Figure 9. Slurry-phase polymerisation ethylene uptake rate as a function of time of polymerisation using sMAO supported $\left.r a c-{ }^{\mathrm{Me}_{2}} \mathrm{SB}^{3-\mathrm{Et}}{ }^{*}\right) \mathrm{ZrCl}_{2}$ (rac - $\mathbf{1}_{\text {sMAO}}$ ) with 0 (black), 125 (red) and $250 \mu \mathrm{L}$ 1-hexene (blue). Polymerisation conditions: $\left[\mathrm{Al}_{\mathrm{sMAO}}\right]_{0} /[\mathrm{Zr}]_{0}=200$, TiBA 
(10 $\mu \mathrm{mol})$, ethylene $(8.3 \mathrm{bar})$, pre-catalyst $(0.05 \mathrm{mg})$, heptane $(5 \mathrm{~mL})$ and $80{ }^{\circ} \mathrm{C}$. Reactions quenched at 5.5 bar ethylene uptake or after 1 hour.

The molecular weights $\left(M_{\mathrm{w}}\right)$ of the polyethylenes produced decrease with increasing 1-hexene concentration, likely resulting from chain termination following 1-hexene insertion and chain transfer to 1-hexene; $[83,84] M_{\mathrm{w}}$ of 1009,585 and $383 \mathrm{~kg} \mathrm{~mol}^{-1}$ with 0,125 and $250 \mu \mathrm{L}$ 1-hexene respectively (Figure S29). $M_{\mathrm{w}} / M_{n}$ also decreased with increasing 1-hexene concentration, indicating controlled copolymerisation $\left(M_{\mathrm{w}} / M_{\mathrm{n}}\right.$ of $6.6,4.8$ and 3.3 with 0,125 and $250 \mu \mathrm{L}$ 1-hexene respectively). The polyethylenes were determined by ${ }^{13} \mathrm{C}\left\{{ }^{1} \mathrm{H}\right\} \mathrm{NMR}$ spectroscopy to have very low 1-hexene incorporation levels; 0.3 and 0.7 mol\% with 125 and $250 \mu \mathrm{L}$ 1-hexene, respectively. This is slightly lower than the incorporation levels recorded for related metallocene catalysts $\mathrm{SMAO}-{ }^{\mathrm{Me}_{2}} \mathrm{SB}\left(\mathrm{Cp}^{\mathrm{R}}, \mathrm{I}^{*}\right) \mathrm{ZrX} 2(0.6-0.7$ and $1.0-1.1 \mathrm{~mol} \%$ with 125 and $250 \mu \mathrm{L}$ 1-hexene respectively in the presence of $0.8 \% \mathrm{H}_{2}$ ),[67] and may be due to the increased steric bulk of ${ }^{3-\mathrm{Et}} \mathrm{I}^{*}$ compared to $\mathrm{Cp}^{\mathrm{R}}$.

\section{Conclusions}

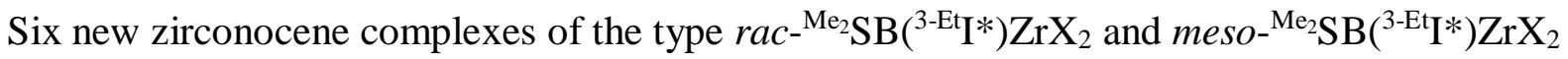
$\left(\mathrm{X}=\mathrm{Cl}, \mathrm{Br}\right.$ and $\mathrm{CH}_{2} \mathrm{Ph}$ ) have been synthesised and fully characterised by NMR spectroscopy and X-ray crystallography. The molecular structures show differences in sterics of the rac-and meso-isomers, with torsion angles of $\sim 145$ and $\sim 0^{\circ}$ reported respectively.

Slurry-phase ethylene polymerisation studies showed that when immobilised on solid polymethylaluminoxane, a 50:50 isomeric mixture of $\mathrm{rac}_{-}{ }^{\mathrm{Me}_{2}} \mathrm{SB}^{\left.3-\mathrm{Et}^{*}\right)} \mathrm{ZrCl}_{2}$ and

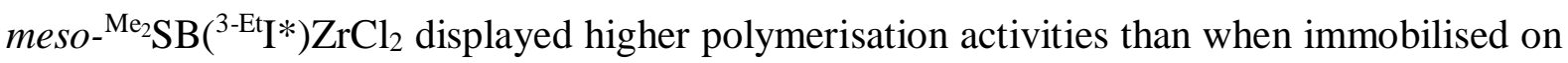
MAO modified silica or MAO modified LDH, and produced HDPE (confirmed by PXRD) with industrially desirable, 'popcorn' morphologies. Polymerisation conditions were optimised for this system and the slurry-phase ethylene polymerisation activities of sMAO supported

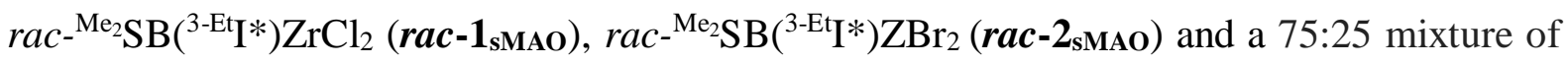
rac- ${ }^{\mathrm{Me}_{2}} \mathrm{SB}\left({ }^{3-\mathrm{Et}} \mathrm{I}^{*}\right) \mathrm{Zr}\left(\mathrm{CH}_{2} \mathrm{Ph}\right)_{2}$ and meso- $\left.^{-{ }^{\mathrm{Me}}} \mathrm{SB}^{3-\mathrm{Et}}{ }^{*}\right) \mathrm{Zr}\left(\mathrm{CH}_{2} \mathrm{Ph}\right)_{2}\left(\mathbf{3}_{\text {SMAO }}\right)$ evaluated. $\mathbf{3}_{\text {sMAO }}$ was found to show the highest polymerisation activities ( $4832 \mathrm{~kg}_{\mathrm{PE}} \mathrm{molzr}^{-1} \mathrm{~h}^{-1} \mathrm{bar}^{-1}$ at $60{ }^{\circ} \mathrm{C}$ ), with modest molecular weights $\left(336 \mathrm{~kg} \mathrm{~mol}^{-1}\right.$ at $\left.60{ }^{\circ} \mathrm{C}\right)$ and molecular weight distributions with $M_{\mathrm{w}} / M_{\mathrm{n}}<3.2$.

In a high-throughput screening system, rac-1 $\mathbf{1}_{\text {sMAO }}$ was found to be responsive to $\mathrm{H}_{2}$, maintaining reasonable activities $\left(640 \mathrm{~kg}_{\mathrm{PE}}\right.$ molzr $^{-1} \mathrm{~h}^{-1} \mathrm{bar}^{-1}$ with $\left.1.6 \% \mathrm{H}_{2}\right)$ and producing 
polymers with low molecular weights $\left(M_{\mathrm{w}}\right.$ of $41 \mathrm{~kg} \mathrm{~mol}^{-1}$ with $\left.1.6 \%\right)$. rac-1 $\mathbf{1}_{\text {sMAo }}$ was also shown to experience increases in polymerisation activity for ethylene/1-hexene copolymerisation compared to ethylene homopolymerisation (4000 $\mathrm{kg}_{\mathrm{PE}} \mathrm{mol}_{\mathrm{Zr}}^{-1} \mathrm{~h}^{-1} \mathrm{bar}^{-1}$ with $250 \mu \mathrm{L}$ 1-hexene), although displayed low 1-hexene incorporation levels (maximum incorporation of $0.7 \mathrm{~mol} \%$ ).

\section{Experimental}

Synthesis of ${ }^{M e_{2}} \mathrm{SB}\left({ }^{3-E t} I^{*}\right) \mathrm{H}_{2}$

2.0 equivalents ${ }^{3-E t} \operatorname{Ind}^{\#} \mathrm{Li}(2.00 \mathrm{~g}, 9.08 \mathrm{mmol})$ were dissolved in THF $(100 \mathrm{~mL})$, forming a dark brown solution. 1.0 equivalent $\mathrm{Me}_{2} \mathrm{SiCl}_{2}(0.586 \mathrm{~g}, 4.54 \mathrm{mmol})$ diluted in THF (50 mL) was added dropwise to the ${ }^{3-\mathrm{Et}} \mathrm{Ind}^{\#} \mathrm{Li}$ solution at $0{ }^{\circ} \mathrm{C}$. The reaction was allowed to warm up to room temperature and stirred for 16 hours. The pale yellow solution was dried in vacuo, extracted with DCM (200 mL) and the resulting pale yellow filtrate dried in vacuo to yield a 50:50

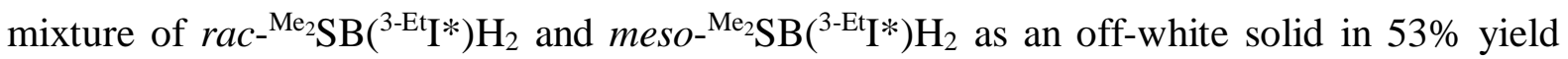

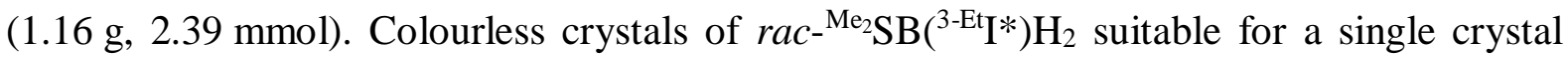
$\mathrm{X}$-ray diffraction study were grown from $\mathrm{Et}_{2} \mathrm{O}$ at $-30{ }^{\circ} \mathrm{C}$. $\mathrm{CHN}$ analysis (\%): calculated C 84.23, H 9.98; observed C 84.10, H 10.15. MS (EI): expected $m / z$ 484.35; observed 484.35. rac ${ }^{\mathrm{Me}_{2}} \mathrm{SB}\left({ }^{3-\mathrm{Et}} \mathrm{I}^{*}\right) \mathrm{H}_{2}:{ }^{1} \mathrm{H}$ NMR (chloroform- $\left.d_{1}, 400 \mathrm{MHz}, 298 \mathrm{~K}\right): \delta(\mathrm{ppm}) 3.74$ (Ind-H, 2H, s), 2.74 (Ind- $\mathrm{CH}_{2}-\mathrm{CH}_{3}, 4 \mathrm{H}, \mathrm{q},{ }^{3} \mathrm{~J}_{\mathrm{HH}}=7.5 \mathrm{~Hz}$ ), 2.46 (Ind-CH3 $, 6 \mathrm{H}, \mathrm{s}$ ), 2.27 (Ind-CH3 $, 6 \mathrm{H}, \mathrm{s}$ ), 2.20 $\left(\right.$ Ind- $\left.\mathrm{CH}_{3}, 6 \mathrm{H}, \mathrm{s}\right), 2.16\left(\right.$ Ind- $\left.\mathrm{CH}_{3}, 12 \mathrm{H}, \mathrm{s}\right), 1.17\left(\right.$ Ind $\left.-\mathrm{CH}_{2}-\mathrm{CH}_{3}, 6 \mathrm{H}, \mathrm{t},{ }^{3} \mathrm{~J}_{\mathrm{HH}}=7.5 \mathrm{~Hz}\right),-0.63$ $\left(\mathrm{Si}-\mathrm{CH}_{3}, 6 \mathrm{H}, \mathrm{s}\right) .{ }^{13} \mathrm{C}\left\{{ }^{1} \mathrm{H}\right\}$ NMR (chloroform- $\left.d_{1}, 101 \mathrm{MHz}, 298 \mathrm{~K}\right): \delta(\mathrm{ppm}) 142.6$ (Ind), 140.6 (Ind), 139.6 (Ind), 139.4 (Ind), 132.4 (Ind), 129.8 (Ind), 127.2 (Ind), 125.8 (Ind), 47.2 (Ind-H)，21.0 (Ind- $\mathbf{C H}_{2}-\mathrm{CH}_{3}$ ), 19.2 (Ind- $\mathbf{C H}_{3}$ ), 16.4 (Ind- $\mathbf{C H}_{3}$ ), 16.4 (Ind- $\mathbf{C H}_{3}$ ), 16.0 (Ind- $\left.\mathrm{CH}_{3}\right), 15.7$ (Ind- $\left.\mathrm{CH}_{3}\right), 14.8\left(\right.$ Ind- $\left.\mathrm{CH}_{2}-\mathrm{CH}_{3}\right),-4.0\left(\mathrm{Si}-\mathrm{CH}_{3}\right)$. meso- ${ }^{\mathrm{Me}_{2}} \mathrm{SB}\left({ }^{3-\mathrm{Et}} \mathrm{I}^{*}\right) \mathrm{H}_{2}:{ }^{1} \mathrm{H}$ NMR (chloroform- $d_{1}, 400$ MHz, $298 \mathrm{~K}$ ): $\delta$ (ppm) 3.60 (Ind-H, 2H, s), 2.67 (Ind-CH2-CH $\mathbf{C H}_{3}, 4 \mathrm{H}$,

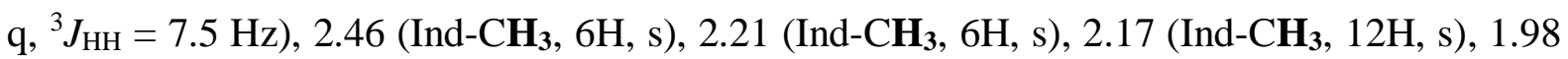
(Ind-CH3 $, 6 \mathrm{H}, \mathrm{s}$ ), 1.12 (Ind- $\mathrm{CH}_{2}-\mathrm{CH}_{3}, 6 \mathrm{H}, \mathrm{t},{ }^{3} J_{\mathrm{HH}}=7.5 \mathrm{~Hz}$ ), $-0.43\left(\mathrm{Si}-\mathrm{CH}_{3}, 3 \mathrm{H}, \mathrm{s}\right),-0.61$ $\left(\mathrm{Si}-\mathrm{CH}_{3}, 3 \mathrm{H}, \mathrm{s}\right) .{ }^{13} \mathrm{C}\left\{{ }^{1} \mathrm{H}\right\}$ NMR (chloroform- $\left.d_{1}, 101 \mathrm{MHz}, 298 \mathrm{~K}\right): \delta$ (ppm) 143.0 (Ind), 140.5 (Ind), 140.1 (Ind), 139.0 (Ind), 132.3 (Ind), 129.8 (Ind), 127.0 (Ind), 125.8 (Ind), 47.1 (Ind-H), 20.9 (Ind- $\mathrm{CH}_{2}-\mathrm{CH}_{3}$ ), 19.1 (Ind- $\mathrm{CH}_{3}$ ), 16.4 (Ind- $\mathrm{CH}_{3}$ ), 16.4 (Ind- $\mathrm{CH}_{3}$ ), 15.9 (Ind- $\left.\mathrm{CH}_{3}\right), 15.0$ (Ind- $\left.\mathrm{CH}_{3}\right), 14.8\left(\right.$ Ind- $\left.\mathrm{CH}_{2}-\mathbf{C H}_{3}\right),-2.1\left(\mathrm{Si}-\mathbf{C H}_{3}\right),-2.6\left(\mathrm{Si}-\mathbf{C H}_{3}\right) . \mathrm{CCDC}$ number: 2024131. 
Synthesis of $\left.{ }^{M e_{2}} \mathrm{SB}^{3-E t}{ }^{*}\right) \mathrm{ZrCl}_{2}(\mathbf{1})$

1.0 equivalent ${ }^{\mathrm{Me}_{2}} \mathrm{SB}\left({ }^{3-\mathrm{Et}} \mathrm{I}^{*}\right) \mathrm{H}_{2}(2.64 \mathrm{~g}, 5.45 \mathrm{mmol})$ was dissolved in THF $(100 \mathrm{~mL})$ to form a pale yellow solution. 2.2 equivalents ${ }^{n} \mathrm{BuLi}(2.5 \mathrm{M}$ in hexanes, $4.79 \mathrm{~mL}, 12.0 \mathrm{mmol}$ ) were added dropwise at $0{ }^{\circ} \mathrm{C}$ and the reaction stirred for 30 minutes. The resulting dark brown solution was dried in vacuo to form ${ }^{\mathrm{Me}_{2}} \mathrm{SB}\left({ }^{3-\mathrm{Et}} \mathrm{I}^{*}\right) \mathrm{Li}_{2}$ as a yellow solid, which was then washed with $\mathrm{Et}_{2} \mathrm{O}(50 \mathrm{~mL})$ and pentane $(2 \times 50 \mathrm{~mL}) .1 .0$ equivalent $\mathrm{ZrCl}_{4}(1.27 \mathrm{~g}, 5.45 \mathrm{mmol})$ was added to ${ }^{\mathrm{Me}} \mathrm{SB}\left({ }^{3-\mathrm{Et}} \mathrm{I}^{*}\right) \mathrm{Li}_{2}$ and stirred in benzene $(100 \mathrm{~mL})$ for 16 hours at room temperature, resulting in a red solution. The reaction mixture was allowed to settle before being filtered. The red filtrate was dried in vacuo to afford an orange solid which was washed with $\mathrm{Et}_{2} \mathrm{O}(50 \mathrm{~mL})$ to yield a 50:50 mixture of $\mathrm{rac}_{-}{ }^{\mathrm{Me}_{2}} \mathrm{SB}\left({ }^{3-\mathrm{Et}} \mathrm{I}^{*}\right) \mathrm{ZrCl}_{2}$ and meso- $\left.{ }^{\mathrm{Me}_{2}} \mathrm{SB}^{3-\mathrm{Et}} \mathrm{I}^{*}\right) \mathrm{ZrCl}_{2}(\mathbf{1})$ as an orange solid in $24 \%$ yield $(0.850 \mathrm{~g}, 1.32 \mathrm{mmol})$. Orange crystals of $r a c-{ }^{\mathrm{Me}_{2}} \mathrm{SB}\left({ }^{3-\mathrm{Et}} \mathrm{I}^{*}\right) \mathrm{ZrCl}_{2}($ rac -1$)$ and meso- ${ }^{\mathrm{Me}_{2}} \mathrm{SB}\left({ }^{3-\mathrm{Et}} \mathrm{I}^{*}\right) \mathrm{ZrCl}_{2}$ (meso-1) suitable for single crystal X-ray diffraction studies were

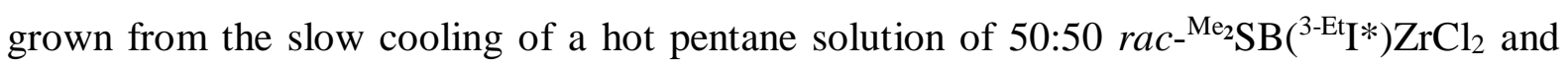
meso- ${ }^{\mathrm{Me}_{2}} \mathrm{SB}\left({ }^{3-\mathrm{Et}}{ }^{*}\right) \mathrm{ZrCl}_{2}$. CHN analysis (\%): calculated C 63.32, $\mathrm{H} 7.19$; observed $\mathrm{C} 63.16, \mathrm{H}$ 7.29. MS (EI): expected $\mathrm{m} / \mathrm{z}$ 642.18; observed 642.18. $\mathrm{rac}_{-}{ }^{\mathrm{Me}_{2}} \mathrm{SB}^{\left.3-\mathrm{Et}^{*}\right)} \mathrm{ZrCl}_{2}:{ }^{1} \mathrm{H} \mathrm{NMR}$ (benzene- $\left.d_{6}, 400 \mathrm{MHz}, 298 \mathrm{~K}\right) \delta(\mathrm{ppm}): 3.30\left(\right.$ Ind- $\mathrm{CH}_{2}-\mathrm{CH}_{3}, 2 \mathrm{H}, \mathrm{dq},{ }^{2} J_{\mathrm{HH}}=15.2 \mathrm{~Hz},{ }^{3} J_{\mathrm{HH}}=$ $7.6 \mathrm{~Hz}$ ), 2.71 (Ind- $\mathrm{CH}_{2}-\mathrm{CH}_{3}, 2 \mathrm{H}, \mathrm{dq},{ }^{2} J_{\mathrm{HH}}=15.2 \mathrm{~Hz},{ }^{3} J_{\mathrm{HH}}=7.6 \mathrm{~Hz}$ ), 2.54 (Ind-CH3 $, 6 \mathrm{H}, \mathrm{s}$ ), 2.35 (Ind- $\mathrm{CH}_{3}, 6 \mathrm{H}, \mathrm{s}$ ), 2.24 (Ind- $\mathrm{CH}_{3}, 6 \mathrm{H}, \mathrm{s}$ ), 2.04 (Ind-CH3 $, 6 \mathrm{H}, \mathrm{s}$ ), 1.92 (Ind-CH$, 6 \mathrm{H}, \mathrm{s}$ ), $1.14\left(\mathrm{Si}-\mathrm{CH}_{3}, 6 \mathrm{H}, \mathrm{s}\right.$ ), 0.86 (Ind- $\mathrm{CH}_{2}-\mathrm{CH}_{3}, 6 \mathrm{H}, \mathrm{t},{ }^{3} \mathrm{~J}_{\mathrm{HH}}=7.6 \mathrm{~Hz}$ ). ${ }^{13} \mathrm{C}\left\{{ }^{1} \mathrm{H}\right\}$ NMR (benzene- $d_{6}$, $101 \mathrm{MHz}, 298 \mathrm{~K}) \delta$ (ppm): 135.2 (Ind), 134.6 (Ind), 134.3 (Ind), 131.0 (Ind), 129.9 (Ind), 128.7 (Ind), 128.2 (Ind), 127.9 (Ind), 79.2 (Ind-Si), 23.0 (Ind- $\mathbf{C H}_{2}-\mathrm{CH}_{3}$ ), 22.4 (Ind- $\mathrm{CH}_{3}$ ), 17.5 (Ind- $\mathrm{CH}_{3}$ ), 17.0 (Ind- $\mathrm{CH}_{3}$ ), 16.7 (Ind- $\mathrm{CH}_{3}$ ), 15.3 (Ind- $\mathrm{CH}_{3}$ ), 15.0 (Ind- $\mathrm{CH}_{2}-\mathrm{CH}_{3}$ ), 10.8 $\left(\mathrm{Si}_{-} \mathrm{CH}_{3}\right)$. meso- $\left.{ }^{\mathrm{Me}_{2}} \mathrm{SB}^{3-\mathrm{Et}}{ }^{*}\right) \mathrm{ZrCl}_{2}:{ }^{1} \mathrm{H} \mathrm{NMR}$ (chloroform- $\left.d_{1}, 400 \mathrm{MHz}, 298 \mathrm{~K}\right) \delta$ (ppm): 3.15 $\left(\right.$ Ind- $\mathrm{CH}_{2}-\mathrm{CH}_{3}, 2 \mathrm{H}, \mathrm{dq},{ }^{2} J_{\mathrm{HH}}=15.2 \mathrm{~Hz},{ }^{3} J_{\mathrm{HH}}=7.6 \mathrm{~Hz}$ ), $2.67\left(\right.$ Ind- $\mathrm{CH}_{2}-\mathrm{CH}_{3}, 2 \mathrm{H}, \mathrm{dq},{ }^{2} J_{\mathrm{HH}}=$

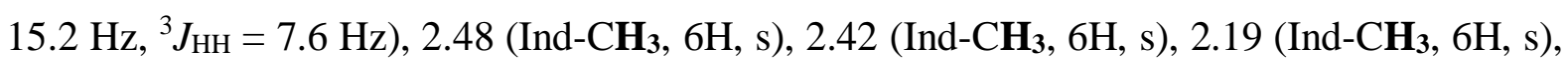

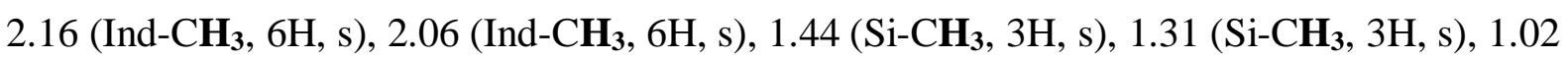
(Ind- $\mathrm{CH}_{2}-\mathrm{CH}_{3}, 6 \mathrm{H}, \mathrm{t},{ }^{3} J_{\mathrm{HH}}=7.6 \mathrm{~Hz}$ ). ${ }^{13} \mathrm{C}\left\{{ }^{1} \mathrm{H}\right\}$ NMR (benzene- $\left.d_{6}, 101 \mathrm{MHz}, 298 \mathrm{~K}\right) \delta(\mathrm{ppm})$ : 134.9 (Ind), 134.5 (Ind), 134.2 (Ind), 134.1 (Ind), 133.5 (Ind), 130.6 (Ind), 129.4 (Ind), 128.8 (Ind), 78.2 (Ind-Si), 22.8 (Ind- $\mathrm{CH}_{3}$ ), 22.7 (Ind- $\mathrm{CH}_{2}-\mathrm{CH}_{3}$ ), 17.3 (Ind- $\mathrm{CH}_{3}$ ), 16.6 (Ind- $\mathrm{CH}_{3}$ ), $16.6\left(\right.$ Ind- $\left.\mathrm{CH}_{3}\right), 15.6$ (Ind- $\left.\mathrm{CH}_{3}\right), 14.2\left(\right.$ Ind- $\left.\mathrm{CH}_{2}-\mathrm{CH}_{3}\right), 14.0\left(\mathrm{Si}-\mathrm{CH}_{3}\right), 9.6\left(\mathrm{Si}-\mathrm{CH}_{3}\right) . \mathrm{CCDC}$ number: 2024132.

Synthesis of $\left.\mathrm{rac}^{-{ }^{e_{2}}} \mathrm{SB}^{3-E t}{ }^{*}\right) \mathrm{ZrBr}_{2}($ rac-2) 
1.0 equivalent ${ }^{\mathrm{Me}_{2}} \mathrm{SB}\left({ }^{3-\mathrm{Et}} \mathrm{I}^{*}\right) \mathrm{H}_{2}(3.30 \mathrm{~g}, 6.81 \mathrm{mmol})$ was dissolved in THF $(100 \mathrm{~mL})$ to form a pale yellow solution. 2.2 equivalents ${ }^{n} \mathrm{BuLi}(2.5 \mathrm{M}$ in hexanes, $5.99 \mathrm{~mL}, 15.0 \mathrm{mmol})$ were added dropwise to the solution at $0{ }^{\circ} \mathrm{C}$ and the reaction stirred for 30 minutes at $0{ }^{\circ} \mathrm{C}$. The resulting dark brown solution was dried in vacuo to form a yellow solid, which was washed with $\mathrm{Et}_{2} \mathrm{O}(50 \mathrm{~mL})$ and pentane $(2 \times 50 \mathrm{~mL})$. 1.0 equivalent $\mathrm{ZrBr}_{4}(2.80 \mathrm{~g}, 6.81 \mathrm{mmol})$ was mixed with ${ }^{\mathrm{Me}_{2}} \mathrm{SB}\left({ }^{3-\mathrm{Et}} \mathrm{I}^{*}\right) \mathrm{Li}_{2}$ (yellow solid) and stirred in benzene $(100 \mathrm{~mL}$ ) for 16 hours at room temperature, resulting in a red solution. The reaction mixture was allowed to settle, filtered and

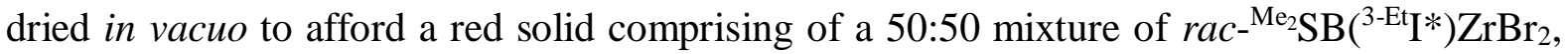
meso- ${ }^{\mathrm{Me}_{2}} \mathrm{SB}\left({ }^{3-\mathrm{Et}}{ }^{*}\right) \mathrm{ZrBr}_{2}$ and impurities. Recrystallisation of the isomeric mixture in $\mathrm{Et}_{2} \mathrm{O}$ at $-30{ }^{\circ} \mathrm{C}$ yielded $\left.\mathrm{rac}^{-{ }^{\mathrm{Me}}} \mathrm{SB}^{3-\mathrm{Et}} \mathrm{I}^{*}\right) \mathrm{ZrBr}_{2}$ (rac-2) as orange crystals in $1 \%$ yield $(68.6 \mathrm{mg}$,

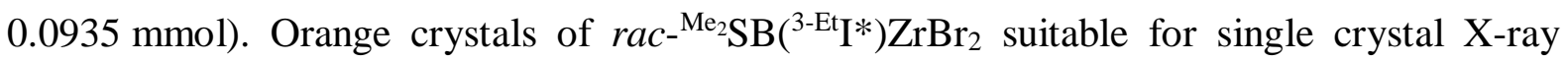
diffraction were grown by slow evaporation of a $\mathrm{Et}_{2} \mathrm{O}$ solution of the isomer. Orange crystals of $m e s O_{-}{ }^{{ }^{{ }_{2}}}{ }_{2} \mathrm{SB}\left({ }^{3-\mathrm{Et}} \mathrm{I}^{*}\right) \mathrm{ZrBr}_{2}$ suitable for single crystal X-ray diffraction were grown by the slow evaporation of a chloroform- $d_{1}$ solution of the isomeric mixture. $r a c-{ }^{\mathrm{Me}_{2}} \mathrm{SB}\left({ }^{3-\mathrm{Et}} \mathrm{I}^{*}\right) \mathrm{ZrBr}_{2}:{ }^{1} \mathrm{H}$ NMR (chloroform- $\left.d_{1}, 400 \mathrm{MHz}, 298 \mathrm{~K}\right) \delta$ (ppm): $3.23\left(\right.$ Ind- $\mathrm{CH}_{2}-\mathrm{CH}_{3}, 2 \mathrm{H}, \mathrm{dq},{ }^{2} J_{\mathrm{HH}}=15.2 \mathrm{~Hz}$, ${ }^{3} J_{\mathrm{HH}}=7.6 \mathrm{~Hz}$ ), 2.65 (Ind- $\mathrm{CH}_{2}-\mathrm{CH}_{3}, 2 \mathrm{H}, \mathrm{dq},{ }^{2} J_{\mathrm{HH}}=15.2 \mathrm{~Hz},{ }^{3} J_{\mathrm{HH}}=7.6 \mathrm{~Hz}$ ), 2.46 (Ind-CH3

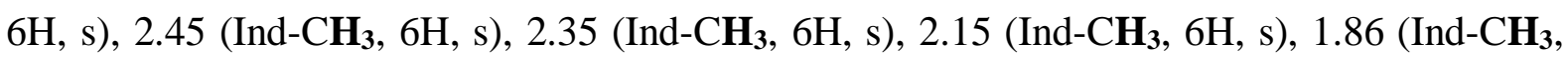
$6 \mathrm{H}, \mathrm{s}), 1.35\left(\mathrm{Si}-\mathrm{CH}_{3}, 6 \mathrm{H}, \mathrm{s}\right), 0.91\left(\right.$ Ind- $\left.\mathrm{CH}_{2}-\mathrm{CH}_{3}, 6 \mathrm{H}, \mathrm{t},{ }^{3} \mathrm{~J}_{\mathrm{HH}}=7.6 \mathrm{~Hz}\right) .{ }^{13} \mathrm{C}\left\{{ }^{1} \mathrm{H}\right\} \mathrm{NMR}$ (chloroform- $d_{1}, 101 \mathrm{MHz}, 298 \mathrm{~K}$ ): $\delta$ (ppm) 135.7 (Ind), 135.6 (Ind), 134.8 (Ind), 134.2 (Ind), 131.3 (Ind), 130.2 (Ind), 128.6 (Ind), 128.4 (Ind), 77.4 (Ind-Si), 24.0 (Ind- $\mathbf{C H}_{2}-\mathrm{CH}_{3}$ ), 22.3

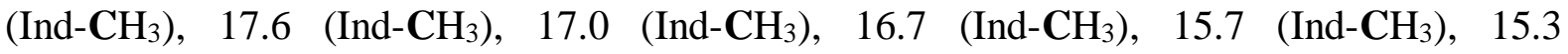
(Ind- $\left.\mathrm{CH}_{2}-\mathrm{CH}_{3}\right), 11.1\left(\mathrm{Si}-\mathrm{CH}_{3}\right)$. CCDC number: 2024133.

Synthesis of $\left.{ }^{\mathrm{Me}_{2}} \mathrm{SB}^{3-E t} \mathrm{I}^{*}\right) \mathrm{Zr}\left(\mathrm{CH}_{2} \mathrm{Ph}\right)_{2}(\mathbf{3})$

1.0 equivalent ${ }^{{ }^{\mathrm{Me}}}{ }_{2} \mathrm{SB}\left({ }^{3-\mathrm{Et}} \mathrm{I}^{*}\right) \mathrm{ZrCl}_{2} \quad(49.5 \mathrm{mg}, 0.0768 \mathrm{mmol})$ and 2.0 equivalents $\mathrm{KCH}_{2} \mathrm{Ph}$ (20.0 mg, $0.154 \mathrm{mmol})$ were mixed in benzene $(1 \mathrm{~mL})$ and stirred for 16 hours at room temperature. The reaction mixture was allowed to settle before being filtered. The orange

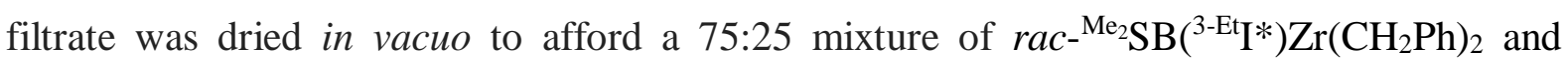
meso- ${ }^{\mathrm{Me}}{ }_{2} \mathrm{SB}\left({ }^{3-\mathrm{Et}} \mathrm{I}^{*}\right) \mathrm{Zr}\left(\mathrm{CH}_{2} \mathrm{Ph}\right)_{2}$ (3) as an orange-yellow solid in $83 \%$ yield $(48.4 \mathrm{mg}$, $0.0640 \mathrm{mmol})$. Orange crystals of $r a c-{ }^{\mathrm{Me}_{2}} \mathrm{SB}\left({ }^{3-\mathrm{Et}} \mathrm{I}^{*}\right) \mathrm{Zr}\left(\mathrm{CH}_{2} \mathrm{Ph}\right)_{2}$ (rac -3) suitable for a single crystal X-ray diffraction study were grown from a pentane solution of the isomeric mixture at room temperature. $r a c_{-}{ }^{\mathrm{Me}_{2}} \mathrm{SB}\left({ }^{3-\mathrm{Et}} \mathrm{I}^{*}\right) \mathrm{Zr}\left(\mathrm{CH}_{2} \mathrm{Ph}\right)_{2}:{ }^{1} \mathrm{H} \mathrm{NMR}$ (chloroform- $\left.d_{1}, 400 \mathrm{MHz}, 298 \mathrm{~K}\right) \delta$ (ppm): $7.00\left(m-\mathrm{Ph}-\mathbf{H}, 4 \mathrm{H}, \mathrm{dd},{ }^{3} J_{\mathrm{HH}}=7.3,7.4 \mathrm{~Hz}\right), 6.73\left(p-\mathrm{Ph}-\mathbf{H}, 2 \mathrm{H}, \mathrm{t},{ }^{3} J_{\mathrm{HH}}=7.3 \mathrm{~Hz}\right), 6.46$

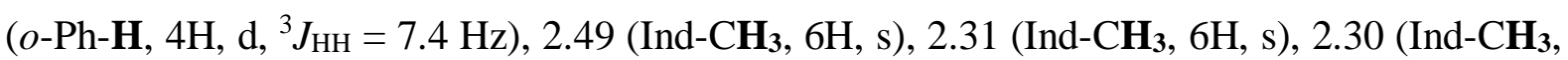


6H, s), 2.26 (Ind-CH3 $, 6 \mathrm{H}, \mathrm{s}$ ), 1.92 (Ind- $\mathrm{CH}_{2}-\mathrm{CH}_{3}, 4 \mathrm{H}, \mathrm{q},{ }^{3} \mathrm{~J}_{\mathrm{HH}}=7.4 \mathrm{~Hz}$ ), 1.84 (Ind-CH3, $6 \mathrm{H}$, s), $1.22\left(\mathrm{Si}-\mathrm{CH}_{3}, 6 \mathrm{H}, \mathrm{s}\right), 0.65\left(\mathrm{Zr}-\mathrm{CH}_{2}-\mathrm{Ph}, 2 \mathrm{H}, \mathrm{d},{ }^{2} \mathrm{~J}_{\mathrm{HH}}=11.5 \mathrm{~Hz}\right), 0.62\left(\right.$ Ind- $\mathrm{CH}_{2}-\mathrm{CH}_{3}, 6 \mathrm{H}, \mathrm{t}$, $\left.{ }^{3} J_{\mathrm{HH}}=7.4 \mathrm{~Hz}\right),-0.29\left(\mathrm{Zr}-\mathrm{CH}_{2}-\mathrm{Ph}, 2 \mathrm{H}, \mathrm{d},{ }^{2} J_{\mathrm{HH}}=11.5 \mathrm{~Hz}\right) \cdot{ }^{13} \mathrm{C}\left\{{ }^{1} \mathrm{H}\right\} \mathrm{NMR}$ (chloroform- $d_{1}$,

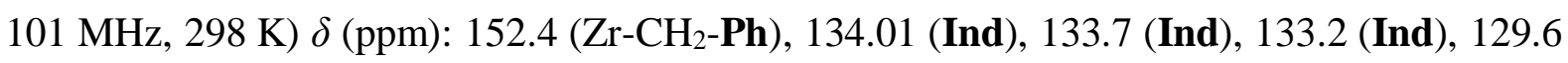
(Ind), 128.9 (Ind), 128.8 (Ind), 128.7 (Ind), 128.5 (Ind), 127.5 ( $\mathrm{m}$-Ph), $126.5(\mathrm{o}-\mathbf{P h}), 121.0$ (p-Ph), 76.4 (Ind-Si), $69.9\left(\mathrm{Zr}-\mathrm{CH}_{2}-\mathrm{Ph}\right), 22.2 \quad$ (Ind- $\left.\mathrm{CH}_{3}\right), 19.9$ (Ind- $\left.\mathbf{C H}_{2}-\mathrm{CH}_{3}\right), 17.6$ (Ind- $\mathrm{CH}_{3}$ ), 16.8 (Ind- $\mathrm{CH}_{3}$ ), 16.7 (Ind- $\mathrm{CH}_{3}$ ), 15.8 (Ind- $\left.\mathrm{CH}_{2}-\mathbf{C H}_{3}\right), 14.5$ (Ind- $\left.\mathrm{CH}_{3}\right), 11.4$ $\left(\mathrm{Si}_{-} \mathrm{CH}_{3}\right)$. meso- ${ }^{\mathrm{Me}_{2}} \mathrm{SB}\left({ }^{3-\mathrm{Et}} \mathrm{I}^{*}\right) \mathrm{Zr}\left(\mathrm{CH}_{2} \mathrm{Ph}\right)_{2}:{ }^{1} \mathrm{H} \mathrm{NMR}$ (chloroform- $\left.d_{1}, 400 \mathrm{MHz}, 298 \mathrm{~K}\right) \delta(\mathrm{ppm})$ : $6.95\left(m-\mathrm{Ph}-\mathbf{H}, 2 \mathrm{H}, \mathrm{dd},{ }^{3} J_{\mathrm{HH}}=7.3,7.6 \mathrm{~Hz}\right), 6.86\left(m-\mathrm{Ph}-\mathbf{H}, 2 \mathrm{H}, \mathrm{dd},{ }^{3} J_{\mathrm{HH}}=7.3,7.6 \mathrm{~Hz}\right), 6.75$ $\left(p-\mathrm{Ph}-\mathbf{H}, 1 \mathrm{H}, \mathrm{t},{ }^{3} J_{\mathrm{HH}}=7.3 \mathrm{~Hz}\right), 6.63\left(p-\mathrm{Ph}-\mathbf{H}, 1 \mathrm{H}, \mathrm{t},{ }^{3} J_{\mathrm{HH}}=7.3 \mathrm{~Hz}\right), 6.25\left(o-\mathrm{Ph}-\mathbf{H}, 2 \mathrm{H}, \mathrm{d},{ }^{3} J_{\mathrm{HH}}\right.$ $=7.6 \mathrm{~Hz}), 6.05\left(o-\mathrm{Ph}-\mathbf{H}, 2 \mathrm{H}, \mathrm{d},{ }^{3} J_{\mathrm{HH}}=7.6 \mathrm{~Hz}\right), 2.49\left(\right.$ Ind- $\mathrm{CH}_{2}-\mathrm{CH}_{3}, 2 \mathrm{H}, \mathrm{m},{ }^{3} J_{\mathrm{HH}}=7.4 \mathrm{~Hz}$, ), 2.41 (Ind- $\mathrm{CH}_{3}, 6 \mathrm{H}, \mathrm{s}$ ), 2.38 (Ind- $\mathrm{CH}_{3}, 6 \mathrm{H}, \mathrm{s}$ ), 2.32 (Ind- $\mathrm{CH}_{2}-\mathrm{CH}_{3}, 2 \mathrm{H}, \mathrm{m},{ }^{3} \mathrm{~J}_{\mathrm{HH}}=7.4 \mathrm{~Hz}$ ), 2.22 (Ind-CH3 $, 6 \mathrm{H}, \mathrm{s}$ ), 2.12 (Ind-CH3, 6H, s), 2.09 (Ind-CH3 , 6H, s), 1.79 (Zr-CH2-Ph, 2H, s), 1.27 $\left(\mathrm{Si}-\mathrm{CH}_{3}, 3 \mathrm{H}, \mathrm{s}\right), 1.17\left(\mathrm{Si}-\mathrm{CH}_{3}, 3 \mathrm{H}, \mathrm{s}\right), 0.91$ (Ind- $\mathrm{CH}_{2}-\mathrm{CH}_{3}, 6 \mathrm{H}, \mathrm{t},{ }^{3} \mathrm{~J}_{\mathrm{HH}}=7.4 \mathrm{~Hz}$ ), -1.03 $\left(\mathrm{Zr}-\mathrm{CH}_{2}-\mathrm{Ph}, 2 \mathrm{H}, \mathrm{s}\right) .{ }^{13} \mathrm{C}\left\{{ }^{1} \mathrm{H}\right\} \quad \mathrm{NMR}$ (chloroform- $\left.d_{1}, 101 \mathrm{MHz}, 298 \mathrm{~K}\right) \delta$ (ppm): 152.0 ( $\mathrm{Zr}-\mathrm{CH}_{2}-\mathbf{P h}$ ), 150.0 ( $\left.\mathrm{Zr}-\mathrm{CH}_{2}-\mathbf{P h}\right), 133.7$ (Ind), 133.4 (Ind), 132.7 (Ind), 131.2 (Ind), 130.7 (Ind), 129.9 (Ind), 129.2 (Ind), 128.8 (Ind), 127.4 (o-Ph), $127.2(\mathrm{~m}$-Ph), 126.9 ( $\mathrm{m}$-Ph), 126.7 (o-Ph), 121.2 (p-Ph), 120.7 (p-Ph), 76.6 (Ind-Si), 67.4 ( $\left.\mathrm{Zr}_{-} \mathrm{CH}_{2}-\mathrm{Ph}\right), 65.5$ ( $\left.\mathrm{Zr}-\mathrm{CH}_{2}-\mathrm{Ph}\right), 23.1$ (Ind- $\mathrm{CH}_{3}$ ), 21.6 (Ind- $\mathrm{CH}_{2}-\mathrm{CH}_{3}$ ), 17.4 (Ind- $\left.\mathrm{CH}_{3}\right), 17.3$ (Ind- $\left.\mathrm{CH}_{3}\right), 16.8$ (Ind- $\left.\mathbf{C H}_{3}\right), 15.2$ (Ind- $\left.\mathrm{CH}_{3}\right), 14.8\left(\mathrm{Si}-\mathrm{CH}_{3}\right), 14.6\left(\right.$ Ind- $\left.\mathrm{CH}_{2}-\mathbf{C H}_{3}\right), 10.4\left(\mathrm{Si}-\mathrm{CH}_{3}\right) . \mathrm{CCDC}$ number: 2024135.

Synthesis of methylaluminoxane modified silica (SSMAO)

2.0 equivalents silica $\left(\mathrm{SiO}_{2}, 2.00 \mathrm{~g}, 33.3 \mathrm{mmol}\right)$ were dispersed in toluene $(25 \mathrm{~mL})$ to form a colourless slurry. 1.0 equivalent MAO $(0.966 \mathrm{~g}, 16.6 \mathrm{mmol})$ was dissolved in toluene $(25 \mathrm{~mL})$ to form a colourless solution which was then quickly added to the silica slurry at room temperature. The reaction mixture was heated to $80{ }^{\circ} \mathrm{C}$ for 2 hours with occasional swirling. The resulting colourless slurry was cooled to room temperature and dried in vacuo to afford the product as a white solid in $88 \%$ yield $(2.62 \mathrm{~g}, 14.7 \mathrm{mmol})$.

Synthesis of methylaluminoxane modified layered double hydroxide (LDHMAO)

2.0 equivalents aqueous miscible organic layered double hydroxide (AMO-LDH) $\left(\mathrm{Mg}_{0.75} \mathrm{Al}_{0.25}(\mathrm{OH})_{2}\left(\mathrm{CO}_{3}\right)_{0.125}, 2.00 \mathrm{~g}, 30.1 \mathrm{mmol}\right)$ were dispersed in toluene $(25 \mathrm{~mL})$ to form a colourless slurry. 1.0 equivalent MAO $(0.873 \mathrm{~g}, 15.0 \mathrm{mmol})$ was dissolved in toluene $(25 \mathrm{~mL})$ to form a colourless solution which was then quickly added to the AMO-LDH slurry at room 
temperature. The reaction mixture was heated to $80{ }^{\circ} \mathrm{C}$ for 2 hours with occasional swirling. The resulting colourless slurry was cooled to room temperature and dried in vacuo to afford the product as a white solid in $92 \%$ yield $(2.64 \mathrm{~g}, 13.8 \mathrm{mmol})$.

Synthesis of SSMAO- ${ }^{M e_{2}} \mathrm{SB}\left({ }^{3-E t} I^{*}\right) \mathrm{ZrCl}_{2}\left(\mathbf{1}_{\text {SSMAO }}\right)$

200 equivalents SSMAO $(0.300 \mathrm{~g}, 1.68 \mathrm{mmol})$ were dispersed in toluene $(25 \mathrm{~mL})$ to form a colourless slurry. 1.0 equivalent of a 50:50 mixture of $\mathrm{rac}_{-}{ }^{\mathrm{Me}_{2}} \mathrm{SB}\left({ }^{3-\mathrm{Et}} \mathrm{I}^{*}\right) \mathrm{ZrCl}_{2}$ and meso- ${ }^{\mathrm{Me}_{2}} \mathrm{SB}\left({ }^{3-\mathrm{Et}} \mathrm{I}^{*}\right) \mathrm{ZrCl}_{2}(5.4 \mathrm{mg}, 0.00842 \mathrm{mmol})$ was dissolved in toluene $(25 \mathrm{~mL})$ to form an orange solution which was then quickly added to the SSMAO slurry at room temperature. The reaction mixture was heated to $60{ }^{\circ} \mathrm{C}$ for 2 hours with occasional swirling. The orange solid was allowed to settle from the clear, colourless solution which was decanted, and the solid was dried in vacuo to afford the product as a pale orange solid in $90 \%$ yield $(0.276 \mathrm{~g})$.

Synthesis of LDHMAO- ${ }^{M e_{2}} \mathrm{SB}\left({ }^{3-E t} I^{*}\right) \mathrm{ZrCl}_{2}\left(\mathbf{1}_{\text {LDHMAO}}\right)$

200 equivalents LDHMAO (0.300 g, $1.57 \mathrm{mmol})$ was dispersed in toluene $(25 \mathrm{~mL})$ to form a colourless slurry. 1.0 equivalent of a $50: 50$ mixture of $\mathrm{rac}_{-}{ }^{\mathrm{Me}_{2}} \mathrm{SB}\left({ }^{3-\mathrm{Et}} \mathrm{I}^{*}\right) \mathrm{ZrCl}_{2}$ and meso- ${ }^{\mathrm{Me}_{2}} \mathrm{SB}\left({ }^{3-\mathrm{Et}}{ }^{*}\right) \mathrm{ZrCl}_{2}(5.1 \mathrm{mg}, 0.00785 \mathrm{mmol})$ was dissolved in toluene (25 $\left.\mathrm{mL}\right)$ to form an orange solution which was then quickly added to the LDHMAO at room temperature. The reaction mixture was heated to $60{ }^{\circ} \mathrm{C}$ for 2 hours with occasional swirling. The yellow solid was allowed to settle from the clear, colourless solution which was decanted, and the solid was dried in vacuo to afford the product as an off-white solid in $94 \%$ yield $(0.288 \mathrm{~g})$.

Synthesis of solid polymethylaluminoxane (sMAO) solid catalysts (1 $1_{S M A O}, \mathbf{r a c}-\mathbf{1}_{S M A O}, \mathrm{rac}-\mathbf{2}_{S M A O}$ and $\mathbf{3}_{\text {sMAO) }}$

200 equivalents sMAO (39.7 or $41.1 \% \mathrm{wt}_{\mathrm{Al}} ; 0.300 \mathrm{~g}, 4.41$ or $4.57 \mathrm{mmol}_{\mathrm{Al}}$ ) were dispersed in toluene $(25 \mathrm{~mL})$ to form a colourless slurry. 1.0 equivalent metallocene complex $(0.0221$ or $0.0229 \mathrm{mmol})$ was dissolved in toluene $(25 \mathrm{~mL})$ to form a coloured solution which was then quickly added to the sMAO at room temperature. An initial aluminium to zirconium ratio ([Al $\left.\left.1_{\mathrm{SMAO}}\right]_{0} /[\mathrm{Zr}]_{0}\right)$ of 200 was used unless stated otherwise. The reaction mixture was heated to $60{ }^{\circ} \mathrm{C}$ for 2 hours with occasional swirling. The coloured solid was allowed to settle from the clear, colourless solution, which was decanted and the solid dried in vacuo to give the product as a faintly coloured powder in $73-92 \%$ yield. $\mathrm{SMAO}-{ }^{\mathrm{Me}_{2}} \mathrm{SB}\left({ }^{3-\mathrm{Et}}{ }^{*}\right) \mathrm{ZrCl}_{2}\left(\mathbf{1}_{\text {sMAO }}\right):{ }^{13} \mathrm{C} \mathrm{CP} / \mathrm{MAS}$ SSNMR: $\delta$ (ppm) -8 (CH 3 in sMAO), 15 (Ind-R), 21 (Ind-R), 128 (Ind), 131 (Ind), 136 (Ind). ${ }^{27}$ Al Hahn-echo MAS SSNMR: $\delta$ (ppm) -92 (Al in sMAO). ${ }^{29}$ Si CP/MAS SSNMR: $\delta$ (ppm) 
-13 $\left(\mathbf{S i}-\mathrm{CH}_{3}\right)$. sMAO- ${ }^{\mathrm{Me}_{2}} \mathrm{SB}\left({ }^{3-\mathrm{Et}}{ }^{*}\right) \mathrm{Zr}\left(\mathrm{CH}_{2} \mathrm{Ph}\right)_{2}\left(\mathbf{3}_{\text {sMAo }}\right):{ }^{13} \mathrm{C}$ CP/MAS SSNMR: $\delta$ (ppm) -8

$\left(\mathbf{C H}_{3}\right.$ in sMAO), 16 (Ind-R), 21 (Ind-R), 128 (Ind), 131 (Ind), 136 (Ind). ${ }^{27} \mathrm{Al}$ Hahn-echo MAS SSNMR: $\delta$ (ppm) -91 (Al in sMAO). ${ }^{29} \mathrm{Si} \mathrm{CP/MAS} \mathrm{SSNMR:} \delta(\mathrm{ppm})-15\left(\mathbf{S i}-\mathrm{CH}_{3}\right),-13$ $\left(\mathrm{Si}-\mathrm{CH}_{3}\right)$.

\section{$50 \mathrm{~mL}$ ethylene polymerisation}

For homogeneous ethylene polymerisation, a metallocene complex ( $0.5 \mathrm{mg}, 1.0$ equivalent), MAO (500 equivalents) and hexane $(50 \mathrm{~mL}$ ) were added to a $150 \mathrm{~mL}$ Rotaflo ampoule containing a stirrer bar. For heterogeneous ethylene polymerisation, a supported metallocene catalyst (10 mg, 1.0 eq complex$)$, TiBA (1000 eq.) and hexane $(50 \mathrm{~mL})$ were added. The ampoule was sealed and degassed before being heated to the desired temperature with a stirring speed of $1000 \mathrm{rpm}$. The ampoule was then opened to ethylene gas ( 2 bar). On completion, the ampoule was closed to ethylene and degassed. The resulting polyethylene was filtered on a glass sintered frit, washed with pentane $(2 \times 25 \mathrm{~mL})$ and dried. All polymerisations were carried out, at least, in duplicate and run for 30 minutes, unless stated otherwise. The activities were reported as an average with \pm 1 ESD error.

$250 \mathrm{~mL}$ slurry-phase ethylene polymerisation

A supported metallocene catalyst (10 mg, 1.0 eq $_{\text {complex }}$ ), TiBA (1000 eq.) and hexane (250 mL) were added to a $500 \mathrm{~mL}$ Rotaflo ampoule containing a stirrer bar. The ampoule was sealed and degassed before being heated to the desired temperature with a stirring speed of $1000 \mathrm{rpm}$. The ampoule was then opened to ethylene gas ( 2 bar). On completion, the ampoule was closed to ethylene and degassed. The resulting polyethylene was filtered on a glass sintered frit, washed with pentane $(2 \times 25 \mathrm{~mL})$ and dried. All polymerisations were carried out, at least, in duplicate and run for 30 minutes. Activities were reported as an average with \pm 1 ESD error.

\section{High-throughput ethylene polymerisation}

Polymerisation experiments were conducted by Dr Alessio Mingione under the supervision of Prof. Vincenzo Busico at HTExplore (University of Naples, Italy) in a Freeslate Parallel Pressure Reactor (PPR) platform consisting of 48 reaction cells contained within a triple MBraun LabMaster Glovebox. The cells (geometric volume $\sim 23 \mathrm{~mL}$, working volume $5 \mathrm{~mL}$ ) were individually controlled with monitoring of temperature and pressure. Slurry-phase polymerisations were run in semi-continuous mode. Two Vortex stir plates fitted with $6 \times 8$ racks held the catalyst system components (pre-catalyst and scavenger). The injection system 
consisted of a dual-arm robot with specialised needles and injectors. Liquid solvents, diluents, and monomers were fed through syringe pumps, with gaseous monomers and diluents fed through direct lines with solenoid valves to individual cells.[85] Heptane solvent (5 mL) and TiBA scavenger $(10 \mu \mathrm{mmol})$ were added to the PPR via robotic syringes, which were then heated to $80{ }^{\circ} \mathrm{C}$ and pressurized to 8.3 bar with ethylene. When required, $\mathrm{H}_{2}$ was added to the reaction vessel via a 0.8 or $1.6 \%$ mixed $\mathrm{H}_{2} / \mathrm{N}_{2}$ feed. Pre-catalyst $(0.30-0.40 \mathrm{mg}$ in heptane slurry) and 1-hexene (when required) were injected with robotic syringes and chased by a certain amount of heptane solvent. The reactions were run for 1 hour or until a certain ethylene uptake was reached (8.3 bar for ethylene homopolymerisation and 5.5 bar for ethylene/1-hexene copolymerisation), following which the reaction was quenched with an excess of dry air. The polymer samples were transferred to a Genevac EZ-Plus centrifugal evaporator to remove volatiles and then dried under vacuum overnight. Inductively coupled plasma (ICP) analysis, ${ }^{13} \mathrm{C}\left\{{ }^{1} \mathrm{H}\right\}$ NMR spectroscopy and gel permeation chromatography (GPC) were carried out at HTExplore, Italy.

\section{Acknowledgments}

P. A., J. V. L., J.-C. B. and Z. R. T. (SCG Research Fellowship) thank SCG Chemicals Co., Ltd. (Thailand) for financial support; Dr Nicholas H. Rees (University of Oxford) for solid-state NMR spectroscopy; Chemical Crystallography (University of Oxford) for the use of the diffractometers; Research Complex at Harwell for use of the Scanning Electron Microscope; Ms Liv Thobru (Norner AS, Norway) for GPC; Prof. Vincenzo Busico (University of Naples) for the use of HTExplore; and Prof. Roberta Cipullo and Dr Alessio Mingione (HTExplore) for running the high-throughput polymerisation experiments and polymer analyses.

\section{References}

1. H. H. Brintzinger, D. Fischer, R. Mülhaupt, B. Rieger and R. M. Waymouth, Angew. Chem., Int. Ed. Engl., 1995, 34, 1143-1170.

2. W. Kaminsky, K. Kulper, H. H. Brintzinger and F. Wild, Angew. Chem., Int. Ed., 1985, 24, 507-508.

3. W. Kaminsky and R. Steiger, Polyhedron, 1988, 7, 2375-2381.

4. W. Kaminsky, R. Engehausen, K. Zoumis, W. Spaleck and J. Rohrmann, Makromol. Chem., 1992, 193, 1643-1651.

5. W. Kaminsky, Macromol. Chem. and Phys., 1996, 197, 3907-3945. 
6. L. Resconi, L. Cavallo, A. Fait and F. Piemontesi, Chem. Rev., 2000, 100, 1253-1346.

7. G. G. Hlatky, Chem. Rev., 2000, 100, 1347-1376.

8. G. G. Hlatky, Coord. Chem. Rev, 1999, 181, 243-296.

9. W. A. Herrmann, J. Rohrmann, E. Herdtweck, W. Spaleck and A. Winter, Angew. Chem., Int. Ed. Engl., 1989, 28, 1511-1512.

10. J.-C. Buffet, T. A. Q. Arnold, Z. R. Turner, P. Angpanitcharoen and D. O'Hare, RSC Adv., 2015, 5, 87456-87464.

11. T. K. Miyamoto, M. Tsutsui and L. B. Chen, Chem. Lett., 1981, 729-730.

12. C. Alonso-Moreno, A. Antiñolo, F. Carrillo-Hermosilla, A. Otero, A. M. Rodríguez, J. Sancho, V. Volkis and M. Eisen, Eur. J. Inorg. Chem., 2006, 2006, 972-979.

13. C. Alonso-Moreno, A. Antiñolo, F. Carrillo-Hermosilla, P. Carrión, A. M. Rodríguez, A. Otero and J. Sancho, J. Mol. Catal. A: Chemical, 2007, 261, 53-63.

14. C. Alonso-Moreno, J. Sancho, F. Carrillo-Hermosilla, A. Otero, A. Antiñolo and I. López-Solera, Inorganic Chemistry Communications, 2009, 12, 184-186.

15. J. R. Severn, J. C. Chadwick, R. Duchateau and N. Friederichs, Chem. Rev., 2005, 105, 4073-4147.

16. J. R. Severn and J. C. Chadwick, Dalton Trans., 2013, 42, 8979-8987.

17. G. Fink, B. Steinmetz, J. Zechlin, C. Przybyla and B. Tesche, Chem. Rev., 2000, 100, 1377-1390.

18. M. M. Mortazavi, S. Ahmadjo, J. H. Z. Dos Santos, H. Arabi, M. Nekoomanesh, G. H. Zohuri, R. Brambilla and G. B. Galland, J. Appl. Polym. Sci., 2013, 130, 4568-4575.

19. D. Bianchini, J. H. Z. dos Santos, T. Uozumi and T. Sano, J. Mol. Catal. A: Chemical, 2002, 185, 223-235.

20. P. Angpanitcharoen, G. Hay, J.-C. Buffet, Z. R. Turner, T. A. Q. Arnold and D. O'Hare, Polyhedron, 2016, 116, 216-222.

21. D. A. X. Fraser, Z. R. Turner, J.-C. Buffet and D. O'Hare, Organometallics, 2016, 35, 2664-2674.

22. J.-C. Buffet, Z. R. Turner, R. T. Cooper and D. O'Hare, Polym. Chem., 2015, 6, 24932503.

23. J.-C. Buffet, N. Wanna, T. A. Q. Arnold, E. K. Gibson, P. P. Wells, Q. Wang, J. Tantirungrotechai and D. O'Hare, Chem. Mater., 2015, 27, 1495-1501.

24. C. Chen, M. Yang, Q. Wang, J.-C. Buffet and D. O'Hare, J. Mater. Chem. A., 2014, 2, 15102-15110.

25. T. A. Q. Arnold, Z. R. Turner, J.-C. Buffet and D. O'Hare, J. Organomet. Chem., 2016, 822, 85-90.

26. T. J. Williams, J.-C. Buffet, Z. R. Turner and D. O'Hare, Catal. Sci. Technol., 2018, 8, 5454-5461.

27. J.-C. Buffet, Z. R. Turner and D. O'Hare, Chem. Commun., 2018, 54, 10970-10973.

28. A. F. R. Kilpatrick, J.-C. Buffet, P. Nørby, N. H. Rees, N. P. Funnell, S. Sripothongnak and D. O'Hare, Chem. Mater., 2016, 28, 7444-7450. 
29. A. F. R. Kilpatrick, N. H. Rees, S. Sripothongnak, J.-C. Buffet and D. O'Hare, Organometallics, 2018, 37, 156-164.

30. J. V. Lamb, J.-C. Buffet, Z. R. Turner and D. O'Hare, Polym. Chem., 2019, 10, 13861398.

31. T. J. Williams, A. D. H. Smith, J.-C. Buffet, Z. R. Turner and D. O'Hare, Mol. Catal., 2020, 486, 110872.

32. J. V. Lamb, J. C. Abell, J. E. McLaren, J.-C. Buffet, Z. R. Turner and D. O'Hare, Mol. Catal., 2020, 484, 110735.

33. J. V. Lamb, J.-C. Buffet, J. E. Matley, C. M. R. Wright, Z. R. Turner and D. O'Hare, Dalton Trans., 2019, 48, 2510-2520.

34. W. J. Gauthier, J. F. Corrigan, N. J. Taylor and S. Collins, Macromolecules, 1995, 28, 3771-3778.

35. T. A. Q. Arnold, J.-C. Buffet, Z. R. Turner and D. O'Hare, J. Organomet. Chem., 2015, 792, 55-65.

36. F. Azimfar, I. Kohsari and S. M. Pourmortazavi, J. Inorg. Organomet. Polym. Mater., 2009, 19, 181-186.

37. M. L. Britto, G. B. Galland, J. H. Z. dos Santos and M. C. Forte, Polymer, 2001, 42, 6355-6361.

38. I. Bravo, C. Alonso-Moreno, F. Carrillo-Hermosilla, I. López-Solera, A. Antiñolo and J. Albaladejo, ChemPlusChem, 2015, 80, 963-972.

39. G. E. Hickman, C. M. R. Wright, A. F. R. Kilpatrick, Z. R. Turner, J.-C. Buffet and D. O’Hare, Mol. Catal., 2019, 468, 139-147.

40. J.-C. Buffet, C. F. H. Byles, R. Felton, C. P. Chen and D. O'Hare, Chem. Commun., 2016, 52, 4076-4079.

41. C. M. R. Wright, K. Ruengkajorn, A. F. R. Kilpatrick, J.-C. Buffet and D. O'Hare, Inorg. Chem., 2017, 56, 7842-7850.

42. P. G. Belelli, M. L. Ferreira and D. E. Damiani, Appl. Catal., A, 2002, 228, 189-202.

43. M. A. Bashir, T. Vancompernolle, R. M. Gauvin, L. Delevoye, N. Merle, V. Monteil, M. Taoufik, T. F. L. McKenna and C. Boisson, Catal. Sci. Technol., 2016, 6, 29622974.

44. A. Tynys, J. L. Eilertsen and E. Rytter, Macromol. Chem. and Phys., 2006, 207, 295303.

45. K.-T. Li, C.-L. Dai and C.-W. Kuo, Catal. Commun., 2007, 8, 1209-1213.

46. F. M. Mirabella Jr. and E. A. Ford, J. Polym. Sci. B: Polym. Phys., 1987, 25, 777-790.

47. A. Maneshi, J. B. P. Soares and L. C. Simon, Macromol. Chem. and Phys., 2011, 212, 2017-2028.

48. K. P. Bryliakov, E. P. Talsi, A. Z. Voskoboynikov, S. J. Lancaster and M. Bochmann, Organometallics, 2008, 27, 6333-6342.

49. V. Busico, R. Cipullo, R. Pellecchia, G. Talarico and A. Razavi, Macromolecules, 2009, 42, 1789-1791.

50. M. Bochmann and S. J. Lancaster, Angew. Chem., Int. Ed., 1994, 33, 1634-1637. 
51. N. V. Semikolenova and V. A. Zakharov, Macromol. Chem. and Phys., 1997, 198, 2889-2897.

52. V. F. Tisse, C. Boisson and T. F. L. McKenna, Macromol. Chem. and Phys., 2014, 215, 1358-1369.

53. W. Michiels and A. Munozescalona, Macromol. Symp., 1995, 97, 171-183.

54. J. Zhang, X. Wang and G.-X. Jin, Coord. Chem. Rev, 2006, 250, 95-109.

55. J. R. Severn and J. C. Chadwick, Macromol. Chem. and Phys., 2004, 205, 1987-1994.

56. D. G. Boucher, I. W. Parsons and R. N. Haward, Macromol. Chem. and Phys., 1974, 175, 3461-3473.

57. K. F. Liu, Q. L. Wu, X. D. Mu, W. Gao and Y. Mu, Polyhedron, 2013, 52, 222-226.

58. T. K. Trefz, M. A. Henderson, M. Linnolahti, S. Collins and J. S. McIndoe, Chemistry - A European Journal, 2015, 21, 2980-2991.

59. S. Collins, M. Linnolahti, M. G. Zamora, H. S. Zijlstra, M. T. Rodríguez Hernández and O. Perez-Camacho, Macromolecules, 2017, 50, 8871-8884.

60. J.-N. Pédeutour, H. Cramail and A. Deffieux, J. Mol. Catal. A: Chemical, 2001, 174, 81-87.

61. G. Sivalingam, V. Natarajan, K. R. Sarma and U. Parasuveera, Ind. Eng. Chem. Res., 2008, 47, 8940-8946.

62. M. S. Bhagwat, S. S. Bhagwat and M. M. Sharma, Ind. Eng. Chem. Res., 1994, 33, 2322-2330.

63. A. E. Hamielec and J. B. P. Soares, Prog. Polym. Sci., 1996, 21, 651-706.

64. W. Kaminsky, Catal. Today, 1994, 20, 257-271.

65. V. Busico, R. Pellecchia, F. Cutillo and R. Cipullo, Macromol. Rapid Commun., 2009, 30, 1697-1708.

66. M. A. R. Meier, R. Hoogenboom and U. S. Schubert, Macromol. Rapid Commun., 2004, 25, 21-33.

67. J. V. Lamb, J.-C. Buffet, Z. R. Turner, T. Khamnaen and D. O'Hare, Macromolecules, 2020, 53, 5847-5856.

68. T. J. Williams, J. V. Lamb, J.-C. Buffet, T. Khamnaen and D. O'Hare, in submission.

69. M. D. Christianson, E. H. P. Tan and C. R. Landis, J. Am. Chem. Soc., 2010, 132, 11461-11463.

70. A. Al-Humydi, J. C. Garrison, M. Mohammed, W. J. Youngs and S. Collins, Polyhedron, 2005, 24, 1234-1249.

71. B. M. Moscato, B. Zhu and C. R. Landis, Organometallics, 2012, 31, 2097-2107.

72. D. L. Nelsen, B. J. Anding, J. L. Sawicki, M. D. Christianson, D. J. Arriola and C. R. Landis, ACS Catal., 2016, 6, 7398-7408.

73. O. N. Pirogov and N. M. Chirkov, Polym. Sci. U.S.S.R., 1966, 8, 1985-1991.

74. M. D. F. V. Marques and R. B. Tiosso, J. Mater. Sci. Eng. Adv. Tech., 2011, 4, 149173.

75. J. A. M. Awudza and P. J. T. Tait, J. Polym. Sci. A: Polym. Chem., 2008, 46, 267-277. 
76. A. Novak, M. Bobak, J. Kosek, B. J. Banaszak, D. Lo, T. Widya, W. H. Ray and J. J. de Pablo, J. Appl. Polym. Sci., 2006, 100, 1124-1136.

77. J. C. W. Chien, Z. Yu, M. M. Marques, J. C. Flores and M. D. Rausch, J. Polym. Sci. A: Polym. Chem., 1998, 36, 319-328.

78. M. P. McDaniel, E. D. Schwerdtfeger and M. D. Jensen, J. Catal., 2014, 314, 109-116.

79. Q. Yang, M. D. Jensen and M. P. McDaniel, Macromolecules, 2010, 43, 8836-8852.

80. M. Ystenes, J. Catal., 1991, 129, 383-401.

81. B. J. Banasazak, D. Lo, T. Widya, W. H. Ray, J. J. de Pablo, A. Novak and J. Kosek, Macromolecules, 2004, 37, 9139-9150.

82. R. Quijada, J. Dupont, M. S. L. Miranda, R. B. Scipioni and G. B. Galland, Macromol. Chem. and Phys., 1995, 196, 3991-4000.

83. N. Herfert, P. Montag and G. Fink, Makromol. Chem., 1993, 194, 3167-3182.

84. R. Quijada, G. B. Galland and R. S. Mauler, Macromol. Chem. and Phys., 1996, 197, 3091-3098.

85. V. Busico, R. Cipullo, A. Mingione and L. Rongo, Ind. Eng. Chem. Res., 2016, 55, 2686-2695. 